\title{
Recent Progress in the Rolling Mills-Part II
}

\section{By Akio SUZUKI**}

(continued on from Vol. 24, No. 3)

\section{Advances of Peripheral Technologies}

After all, rolling is an integral technology: without advances in the technologies that support rolling, and without close cooperation between equipment fabricators and steel producers, no progress in rolling technology is possible. Here, I wish to discuss several of those peripheral technologies for their advancement.

\section{Computer Control}

The control technology, particularly that based on fast computers, made a remarkable advances since 1965. This was made possible first by combining the progress achieved in the rolling theory, which was founded on analysis of characteristics of rolling mill and resistance to deformation of the work piece, and the equipment technology including instrumentation and electric machinery, as well as the highly refined operational know-how. At the same time, the general trend of our modern steelmaking works, which had introduced process computers even in their very early days of starting-up towards ultimate perfection of unified production control system, such as illustrated in Fig. $42,{ }^{64)}$ cannot be overlooked.

\section{Mathematical Modeling of Rolling Process}

Mathematical models are indispensable to do computed controlling of rolling, for which a multitude of variables, including thickness, flow stress, tension, diameter of the roll, and friction coefficient, must be considered.

In the case of tandem rolling, in particular, as the results of rolling at a upstream stand affect not only the rolling conditions at downstream stands, but all the stands through the tension imposed on the flying strip, the whole of the tandem mill line has to be treated in a total system..$^{8)}$ For this, there are such models as the plastic deformation model to quantify the behavior of steel, the elastic deformation model to determine the deformation of mill, the continuous rolling model that describes the tandem rolling, and the heat transfer model to calculate the temperature changes in the strip are available. ${ }^{65)}$

However, those models are all subjected to certain limitations to apply to practice. Therefore, the learning control, in which the states of process are detected by various sensors and fed back to computer to modify the model so as to absorb the fluctuations in the working conditions and other perturbations, is necessary. For this, good sensors are the primary requisite.

\section{Trends in Instruments and Sensors}

(1) The Position Detector

As for tracking of work stock, the hot metal detector (HMD) and the cold metal detector (CMD) are most popular. However, as they are liable to malfunctioning in an adversary atmosphere, sensors that operate on microwave, electromagnetism, or laser are being developed. ${ }^{67}$

(2) The Load Cell

High precision measurement of rolling load is one of the most fundamental for controlling of any rolling mill. There are several reliable ones, of which three are shown in Fig. 43 for their working principles and features. ${ }^{75}$

\section{(3) The Pyrometer}

The radiation pyrometers are being used most commonly for measuring the rolling line temperature, but their precision and stability are not always satisfactory in certain atmospheres and for certain materials. ${ }^{68)}$ Those shortcomings are being corrected. Besides, the so-called pattern measurement, in which, for example, temperature distribution across the width rather than the traditional point to point measurement, is being developed.

(4) The Gagemeter

Meters working on either X-ray or gamma-ray are the most widely used today. ${ }^{69,70)}$ Recent trends

* Presented to the 57-58th Nishiyama Memorial Seminar, March 1980, at Nogyo Kaikan in Okayama and at Nokyo Hall in Tokyo. (C) 1984 ISIJ

Part I has already been published in Transactions ISIJ, 24 (1984), No. 3 (March), 228. The contents are as follows:

Chapter I. Introduction

Chapter II. Progress of Rolling Equipment

1. Improvements in the Productivity 2. Improvement in Quality

Chapter III. Recent Rolling Equipment

1. Hydraulic Press-down 2. Power Downcoiler 3. High Speed Pickling

4. Fully Continuous Cold Rolling Mill 5. The 6-high Mill 6. Continuous Annealing Line

7. Recent Reeling Equipment-Continuous Reel-in and Reel-out Machine for Strip-making

8. Continuous Rolling of H Steels 9. High Speed Rolling of Wire Rods-The Block Mill

10. Direct Patenting

References 1) 63)

** Kakogawa Works, Kobe Steel, Ltd., Kanazawa-cho, Kakogawa 675-01. 
Fig. 42. Information processing network of a steel works.

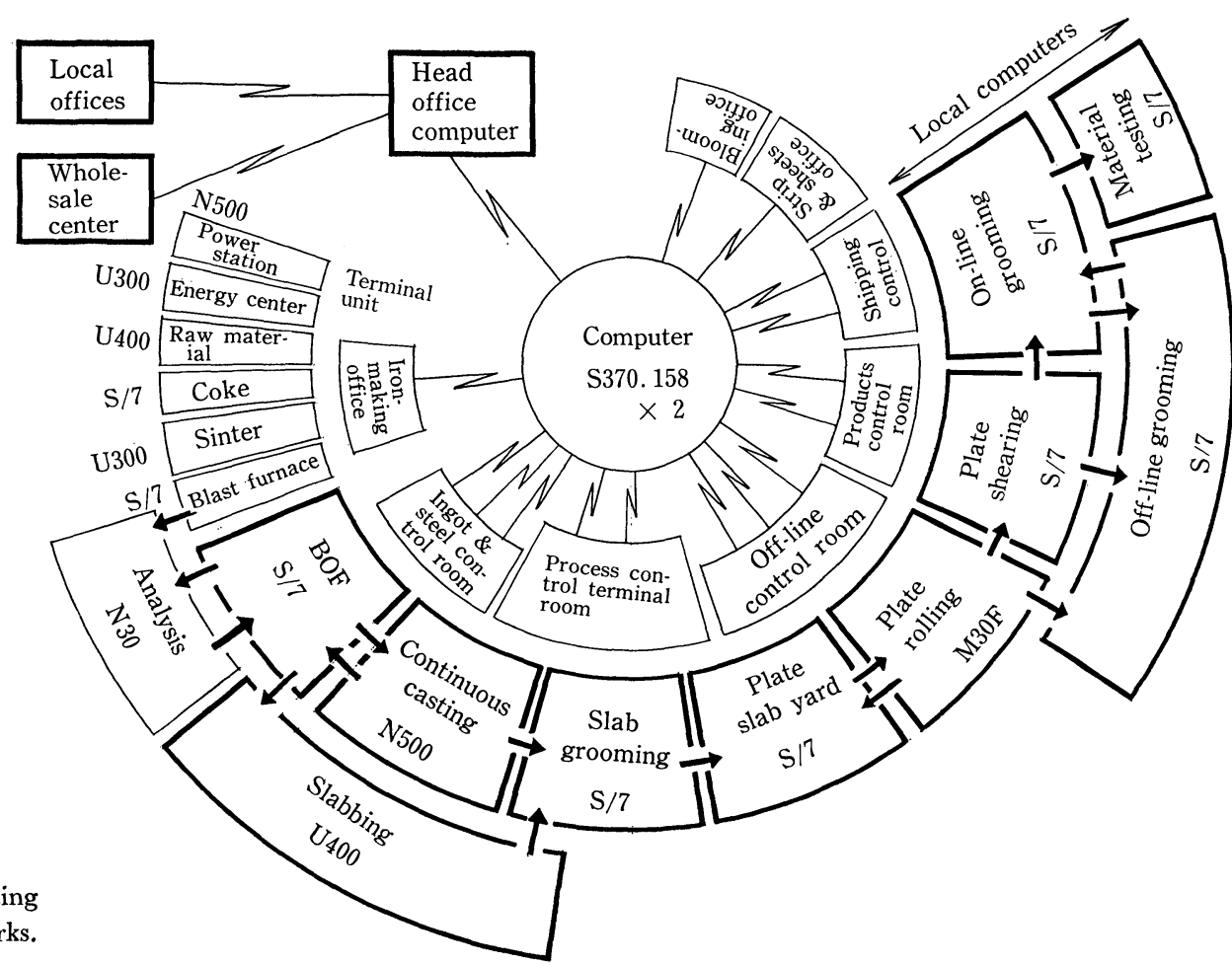

\begin{tabular}{|c|c|c|c|}
\hline Type & Working mechanism & Principle & Feature \\
\hline $\begin{array}{l}\text { Magneto-striction } \\
\text { (Presductor type) }\end{array}$ & $\begin{array}{c}\text { (a) Outlook } \\
\text { Out. }\end{array}$ & $\begin{array}{l}\text { Magnetic materials }(\mathrm{Fe}, \mathrm{Ni} \text {, etc.) change their } \\
\text { magnetic properties when deformed. This } \\
\text { relation is utilized to produce changes in } \\
\text { inductance or voltage in a coil. }\end{array}$ & $\begin{array}{l}\text { Great mechanical } \\
\text { strength } \\
\text { Simple maintenance } \\
\text { Large output }\end{array}$ \\
\hline $\begin{array}{l}\text { Wire strain gage } \\
\text { (Washer type) }\end{array}$ & $\begin{array}{ll}\text { (a) Strain gage } & \text { (b) Outlook } \\
\text { Lead wire }\end{array}$ & $\begin{array}{l}\text { The resistivity of metals changes as they are } \\
\text { stretched or contracted. The strain gage } \\
\text { wire is deformed as the load cell casing is } \\
\text { strained, to induce an electrical change. }\end{array}$ & $\begin{array}{l}\text { High precision } \\
\text { Small hysteresis } \\
\text { Fast response } \\
\text { The load cell be- } \\
\text { comes rather tall }\end{array}$ \\
\hline $\begin{array}{l}\text { Electrostatic } \\
\text { capacitance }\end{array}$ & $\begin{array}{ll}\text { (a) Outlook } & \text { (b) Structure of electrode } \\
\text { Load } & \text { The gap } d \text { changes as } \\
\text { the load changes. }\end{array}$ & $\begin{array}{l}\text { The strain of the load cell casing is picked up } \\
\text { as change in the electrode gap, } d \text {, or the } \\
\text { change in capacitance. This is utilized to } \\
\text { modulate the high frequency oscillation, or } \\
\text { is measured with an autodyne capacitance } \\
\text { meter. }\end{array}$ & $\begin{array}{l}\text { Great mechanical } \\
\text { strength } \\
\text { Fast response } \\
\text { Small error for } \\
\text { uneven loads } \\
\text { The load cell is } \\
\text { compact. }\end{array}$ \\
\hline
\end{tabular}

Fig. 43. Working principles and features of representative load cells.

are for profile measurement and to improve the precision by the use of microcomputers.

(5) The Widthmeter

The optical method is predominant. One variety is the direct method that detects the radiation coming from the work itself, while the other is the indirect method, in which the shadows cast by independent light sources are detected. As an application, further, an apparatus that is capable of measuring both the width and the camber at the same time has been developed. ${ }^{71}$
(6) The Speedometer

The tachometer method, in which the revolutional speed of roll is measured with pulse generator, is most generally used, but this method is liable to errors by fluctuations in roll diameter or in forward slip. Recently, a non-contact speedometer that measures directly the motion of the steel on space filter principle has made appearance. ${ }^{72)}$

\section{Automatic Gage Control (AGG)}

Recent improvements in AGC, which is already as old as advanced rolling technology itself, have 
Table 10. Main AGG components for rolling mills.

\begin{tabular}{l|l|l|l}
\hline & \multicolumn{1}{|c|}{ Plate mill } & \multicolumn{1}{c}{ Hot strip mill } & \multicolumn{1}{c}{ Cold strip mill } \\
\hline AGG functions & $\begin{array}{l}\text { Press-down control with } \\
\text { gagemeter }\end{array}$ & $\begin{array}{l}\text { Press-down control with gagemeter } \\
\text { X-ray monitor } \\
\text { Feed forward control }\end{array}$ & $\begin{array}{l}\text { Press-down control with } \\
\text { gagemeter }\end{array}$ \\
\hline Compensator & $\begin{array}{l}\text { For width } \\
\text { For gain }\end{array}$ & $\begin{array}{l}\text { For top and bottom ends } \\
\text { For press-down } \\
\text { For ac-/deceleration }\end{array}$ & $\begin{array}{l}\text { For top and bottom ends } \\
\text { For ac-/deceleration } \\
\text { For roll eccentricity } \\
\text { For oil film thickness }\end{array}$ \\
\hline Press-down & Electric drive & Electric drive & $\begin{array}{l}\text { Hydraulic drive } \\
\text { Electric drive }\end{array}$ \\
\hline Mill constant $(\mathrm{t} / \mathrm{mm})$ & $700 \sim 1200$ & $400 \sim 600$ & $200 \sim 3500$ (Variable) \\
\hline
\end{tabular}

been for increasing the precision more and more to meet the progressively exacting demand of uniform thickness. Major AGG systems are summarized in Table 10. Besides those, the mass flow AGC and the absolute value AGG are being developed.

However, the present trends are to adopt the DDC (direct digital control) by process computer in place of hardware AGC. This software approach is more economical as it is capable of handling a number of loops at the same time and with complex logics, is more reliable as it is free from the drift often seen in the analogue AGCs, and is much easier to maintain. ${ }^{73,74)}$

\section{Computer Gontrol for Hot Strip Mill}

Hot strip mills are one of the most advanced in the computer control, so much so that of the 20 operating hot strip mills of this country, as many as 15 are computer controlled. The object of modern computer controlling has been extended from the unit mill control, such as automatic setting of individual finisher mills, to the whole line control covering from the entry control at reheating furnace to the coil conveyor control.

The functions of the process computer are thus dual: the automatic controlling by setting the working conditions, on one hand, and the information processing including commands delivery, tracking of the stock, and logging of achievements, on the other. Factual examples are shown in Fig. 44 for system architecture and functions, in Fig. 45 for effects of computer control on gage precision improvement, ${ }^{76)}$ and in Fig. 46 for effects on cooling of the products. ${ }^{76)}$

\section{Optimum Controlling System for Reheating Furnace}

The energy saving at and around the blooming line since the Oil Crisis has been truly remarkable. Particularly, the fuel rate of reheating furnace has been cut down to $1 / 2$ to $1 / 3$ in those several years. This was achieved mostly by utilizing cleverly the sensible and latent heats of ingots, but progress in the heat technology, operation techniques, and studies of flow of heat inside the ingot have made their contributions, so that today such refined control of combustion in accordance with the particulars of the charged ingots is possible.

In recent years, further, with the realization and

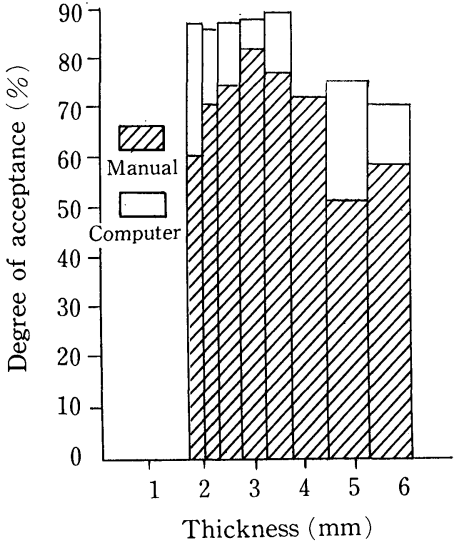

Fig. 45. An example of improvement in thickness precision due to introduction of computer control. Degree of acceptance denotes the percentage of coils with a head-to-end thickness difference within the tolerance field of $\pm 0.05 \mathrm{~mm}$.

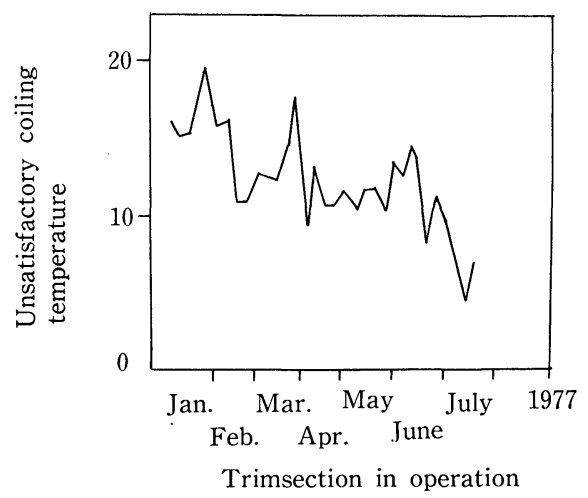

Fig. 46. An example of the effects of product cooling control.

rapid spreading of direct charge rolling, adjustment at the reheating furnace of imbalance between the steel tapping and the rolling timing is being called for. An example of constructing an optimum energy saving control system for combustion control, quality control information processing, and production control is shown in Fig. 47.

Other examples of computer controlling include that for pass scheduling and automatic operation at 


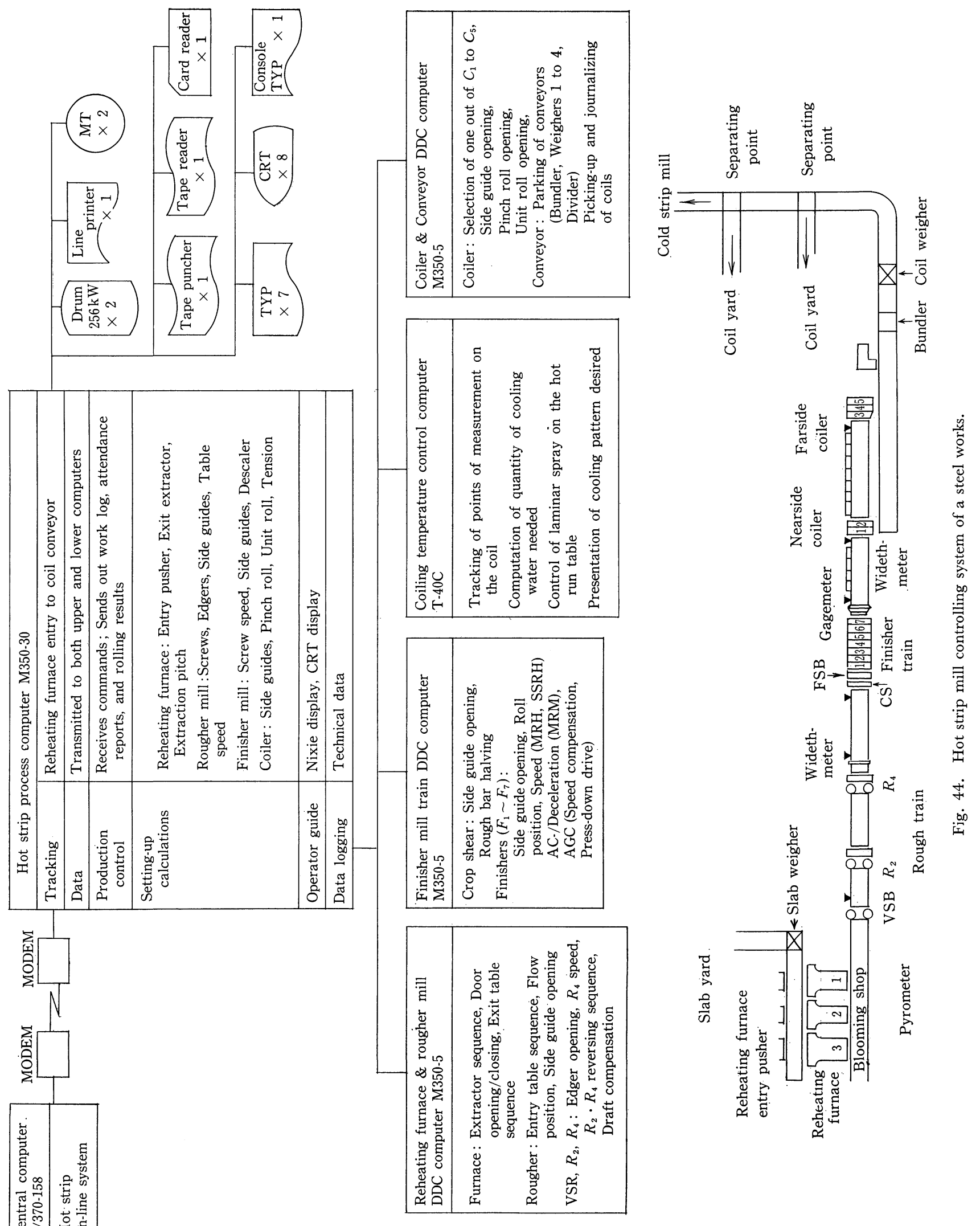

plate mill, gage change of flying strip at cold strip mill, tension control at $\mathrm{H}$ shape continuous mill, and managing of automatic warehouse.

The future prospects of computer controlling will be to adapt itself to the small-lot, multiple-kind production, for which much refined controlling and energy saving function will be required. To implement those, enlargement and sophistication of systems, development of distributed center systems, and extensive utilization of minicomputers and microcomputers will be necessary. Also, the relative importance of softwares as compared to hardwares will be 


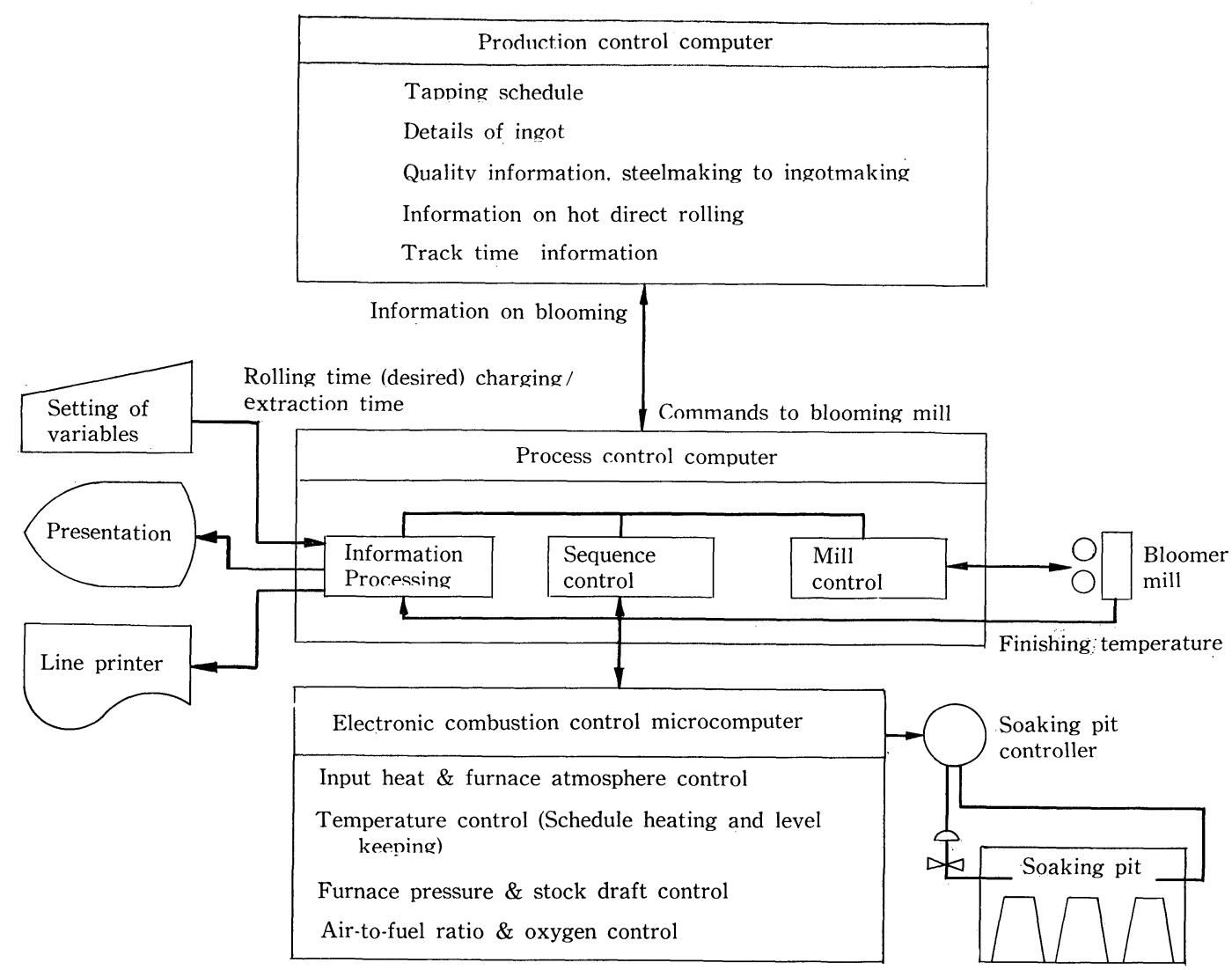

Fig. 47. An example of system structuring for soaking pit optimum control.

increased for effectual systems designing and maintenance.

\section{Hydraulic Technologies ${ }^{77-81)}$}

The intensification of application of hydraulic technologies to modernizing of the rolling mills has been worth a particular mention. Here, I wish to review some of the progress made so far.

\section{Hydraulic Press-down Drive}

The application of hydraulics to press-down drive had already been done for reversing mill many years ago, but its extensive adoption to replace electric press-down started in 1968. First cold tandem mills, then plate finishers, and more recently hot strip mills took up the hydraulic press-down for its excellent response, hence its good compatibility with AGG. At first the press-down cylinder was controlled by mechanical servo mechanism, but nowadays systems that use servo valves are gaining popularity for its even better response. That the hydraulic press-down is on its way to capture the hot strip mill field, whose service circumstances are very adverse because of heat and dust, is proof enough for the advances the hydraulics had achieved. They are more apparent in the following points.

(1) Countermeasures for Contamination of Working Oil

Use of stainless steel for tanks and pipe lines, prefabricated piping for quick and clean assembly, use of manifold method of valve systematization and unitization by module for machinery, pressurization of oil tanks, development of filters with better than
$3 \mu \mathrm{m}$ screening capability, and equipping of tanks with filtration circuit, all helped to prevent contamination of working oil.

(2) Increase of Pressure and Flow Rate

Even though the highest oil pressure for cold strip mills remains to be about $250 \mathrm{~kg} / \mathrm{cm}^{2}$, servo valves that work on pressures of more than $400 \mathrm{~kg} / \mathrm{cm}^{2}$ and for flow rates of over $800 \mathrm{l} / \mathrm{min}$ are being used in the plate mills.

(3) Improvements in Response

The response that was markedly improved on changing from mechanical servo to electro-hydraulic servo is now being improved further by improving the frequency response characteristics of servo valve itself, reducing the friction of hydraulic cylinder ram, and improving the dynamics of the line from servo valve to press-down. An example of hydraulic circuitry for press-down drive is shown in Fig. 48.

\section{Roll Bending}

The roll bending was used to be solely for crown control, but since 1960, when it was first adopted in a cold strip mill, it is gradually taken up by hot strip mills also. Particularly, in cold tandem mills that were installed after 1975, all the stands are equipped with increase-decrease roll bending unit. There is also a hot strip mill that has adapted the increasedecrease roll bending at all the finisher stands. An example of roll bending hydraulic circuitry is shown in Fig. 49.

The pressure control valve was once the electromagnetic depressor type, but nowadays PID type or servo type are used to meet the demand for faster 
Fig. 48.

An example of circuitry for hydraulic press-down drive controlling.
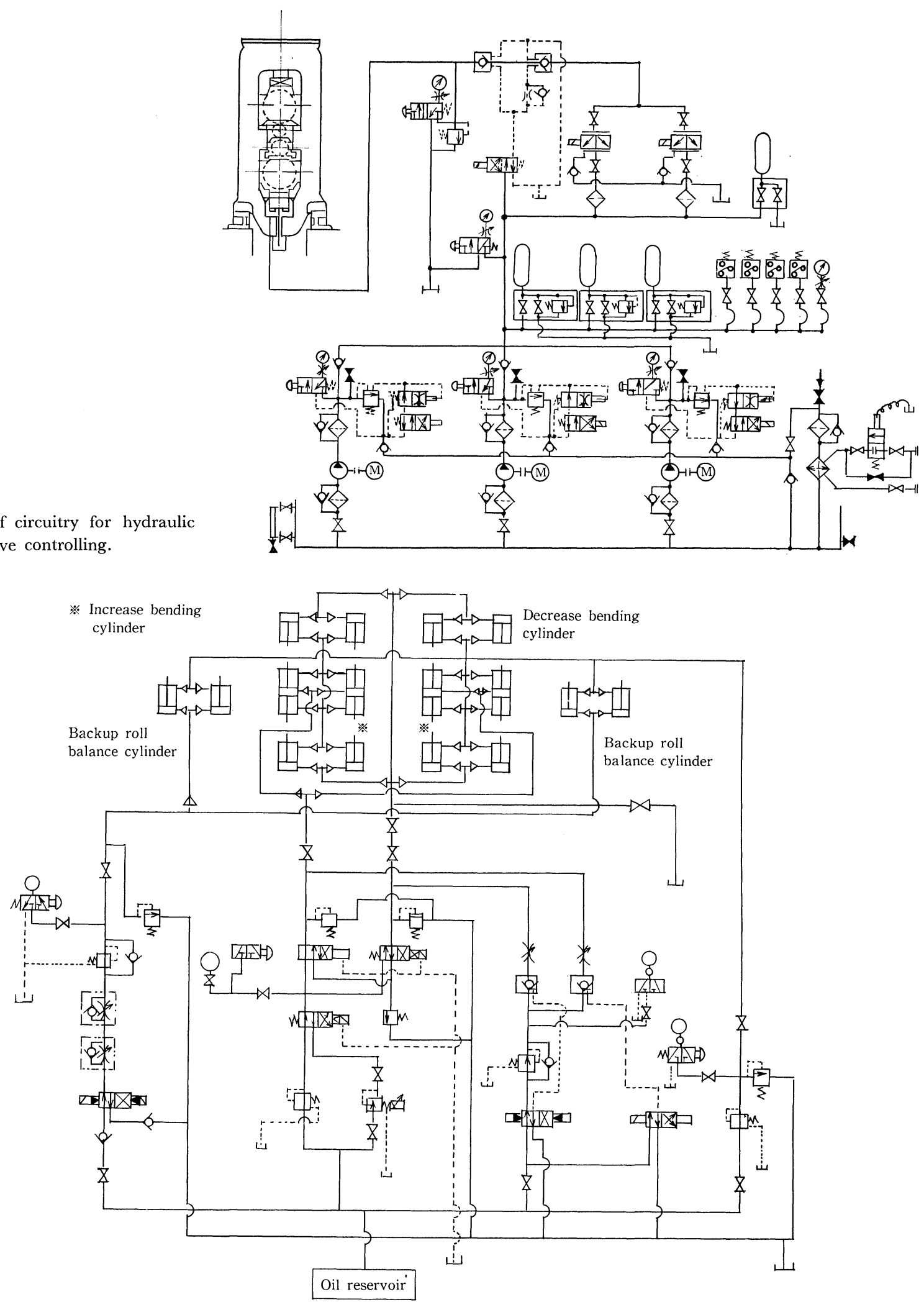

Fig. 49. An example of circuitry for hydraulic bending control.

response and higher precision at the time of engaging and disengaging of the stock.

\section{Other Hydraulic Units}

\section{(1) Roll Balance}

For roll balancing, the hydraulic type has been used along with spring type or counterweight type. The hydraulic type comes in as the suspension type or the integral type in which the single action ram is built-in in the lower roll chock, and, in either case, the counterweight accumulator is provided to balance out the oil pressure with the roll weight and the frictional force.

(2) Hydraulics in the Walking Beam Type Reheating Furnace

The reheating furnace has changed from the pusher type to the walking beam type since 1965 . 
The driving mechanism is either hydraulic or electric cam action, of which the hydraulic is the more popular for its easy control of forward or backward stroke by means only of the cylinder stroke control.

(3) Hydraulics for Auxiliary Machinery

Conversion to hydraulic drive of auxiliary machinery that serve the entry and delivery ends of rolling mills, such as the reciprocating drives and the transfer drives, has begun in 1962 to 63 . In the modern steelmaking works that were built after 1967, in particular, all the important units, like the roll changers and the coil handlers, are hydraulic. This contributed greatly to simplification as well as to automation of the line.

\section{(4) Edge Controller}

The edge controller that works on the jet tube type servo mechanism was used first for prevention of snaking at pickling line, but subsequently, with its speed and capacity appropriately increased for services for high speed mill and large coils, it has been applied successfully to many lines including the annealer, the electric galvanizing, and the spiral pipe making.

\section{Pressurization and Other Progress of Working Fluid}

Pressurization of working fluid has been made possible by advances achieved in oil pumps and other hydraulic components like joints, packings, hose, and in pipe fitting technique. That is, the pressure which remained on the $70 \mathrm{~kg} / \mathrm{cm}^{2}$ level in 1960 was increased to 110 or more in 1970 and after. Further pressurization, in some instances to 210,300 , and as high as $400 \mathrm{~kg} / \mathrm{cm}^{2}$, has also been achieved by solving troubles of vibration and pulsation that attended pressurization.

The working fluid, particularly that for hot rolling mills, has all been the $\mathrm{O} / \mathrm{W}$ (oil and water) emulsion for the sake of fire prevention. Trouble was, however, that the $\mathrm{O} / \mathrm{W}$ fluids were unsatisfactory in the lubrication. For this, extensive research and development was done so that today uninflammable oils as phosphoric acid ester type, fatty acid ester type, or waterglycol type are used.

It is expected that the hydraulic control technology will progress further aided by the electric control technology, so that the servo mechanism will spread to wider areas such as hydraulic looper and VC soft control.

\section{Bearings and Lubrication}

Here, I am going to discuss chiefly the roll neck bearing that has to work under severest conditions.

\section{Progress of Roll Neck Bearing}

Of all the roll neck bearings, the one that works under the most unfavorable condition is the backup roll bearing. Historically, it was plane bearing when used in the world's first 4-high mill of 1891, but this type of bearing was not good enough in the precision of gage. To cover this shortcoming, the roller bearing was used in 1925, but this type was found unsatisfactory in the load capacity as the rolling speed was increased. Then came the hydrodynamic oil film bearing which was commercialized in 1935. Since then most of the backup roll bearings have been of this type. ${ }^{82-84)}$ But, more recently, the roller bearing, which was reinvigorated by advanced lubrication, is regaining popularity for its high precision, particularly for the thin gage mills.

\section{Recent Roll Neck Bearings and Lubrication Tech- nology}

The modern roll neck bearings are much improved over old ones in the materials and structure both for the hydrodynamic type and the roller bearing type, and by the adoption of mist lubrication technique.

(1) Hydrodynamic Oil Film Bearing

(i) Improvements in the Bushing Metal

The bushing metal, which was traditionally the white metal, was first replaced by cadmium alloy for hardness. Because of environmental pollution trouble of cadmium, however, this was replaced with aluminum alloy. But, the hardness of aluminum alloy was too high for bearing, so that white metal of tin base type with improved lining was taken up again.

(ii) Improvements in Seal-Mogoil Bearing as an Example

For hydrodynamic oil film bearings, the care of lubricant to prevent inclusion of moisture and dust as well as leakage is especially important. This calls for a seal that is at the same time of a complex structure and easily replaceable, for which purposes many improvements have been made.

This may be seen in Fig. 50, where (a) is an early model, (b) is a modification to make detaching easy by separating the main body and the seal, (c) is a further improvement to meet the acceleration of mill by using an outer seal and a labrinth, and (d) is today's standard model, in which a reinforcing band has been removed and a spring has been added in the neck seal to alleviate deformation and damage. ${ }^{85}$ )

(iii) Development of Hydrostatic Pressure Bearing

To solve the problem of oil film rupture that is apt to occur under low speed, low load conditions, hydrostatic pressure bearing has been developed. In this bearing, high pressure oil of $700 \mathrm{~kg} / \mathrm{cm}^{2}$ is fed to the bushing thrust plane so as to maintain oil film there while the speed is low. ${ }^{86)}$

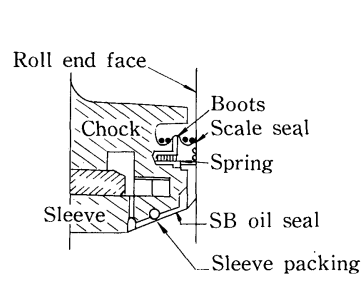

(a)

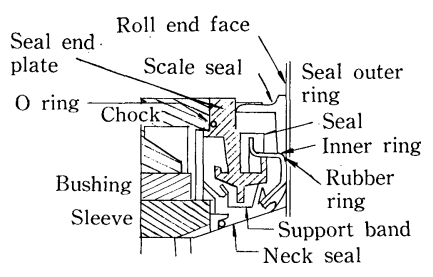

(c)

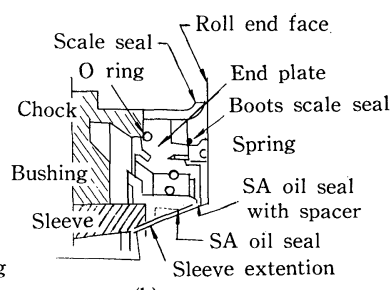

(b)

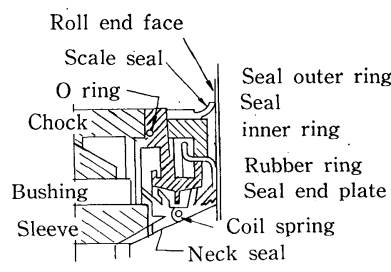

(d)
Fig. 50. Progress of seal structure. 
(2) Roller Bearings ${ }^{87-90)}$

(i) Use of Carburized Steel

In place of conventional high chromium steels, carburized steels are becoming popular. They are known to develop longer service life and better impact strength by controlling the sinter depth and surface concentration of carbon to combine hardness and compressive residual stress at the surface.

(ii) Use of Vacuum Degassed Steel

As the vacuum degassed steels contain markedly less nonmetallic inclusions such as alumina that adversely affect the rolling fatigue, their service life is, as may be seen in Fig. 51, 3 to 10 times the ordinary air melted stock. ${ }^{91,92)}$

(iii) Use of Ring Roll-forged Steel

As compared to conventional free forged or mold forged stock, the ring roll-forged stocks are of the finer grain size and better fiber flow structure, so that they are more resistive to flaking and thus of a longer service life. ${ }^{93}$ )

(iv) Improvement in the Retainer

As may be seen in Fig. 52, the pin type retainer can support 15 to $20 \%$ more rollers than the conventional pressed retainers, so that the basic dynamic load rate can be raised by 10 to $15 \%$. As the weight of retainer is reduced by $40 \%$, further, the relative slip speed of roller to retainer is reduced to $1 / 5$ to ensure good high revolution service.

(v) Crowning of Roller

To uniformize the load distribution that tends to become maximum at the ends of a roller, proper crown is put to the roller.

(3) Use of Roller Bearing for Backup Roll Bearing

The use of roller bearing for the backup roll bearing started in this country with aluminum rolling mill in the last half of 1960s. Since then it was used first in a cold strip mill in 1971, and after that its application is spreading steadily. The maximum speed so far achieved is $1680 \mathrm{~m} / \mathrm{min}$, established by a cold tandem mill. Some comparisons of roller bearing and hydrodynamic oil film bearing as applied to the rackup roll are shown in Table $11 .{ }^{94}$ )

The advantages of using roller bearing are reduction of capital cost and improved quality and precision of products as follows ${ }^{94-97)}$ :

(i) By resorting to the oil mist lubrication, the equipment cost is reduced to $1 / 2$ to $3 / 4$ of the oil film bearing as a whole.

(ii) As may be seen in Fig. 53, the fluctuation in the oil film thickness due to change in rolling speed is markedly smaller.

(iii) As the use of the four-row cylindrical roller allows cogrinding finish to be performed with the inner lace put on, the eccentricity of roll barrel plane to the orbital plane is now reduced to several $\mu \mathrm{m}$.

(iv) As the mill can be started with some pressdown on, and as the starting torque is small, the slip between backup roll and work roll is eliminated to prevent damaging of the rolls. ${ }^{94,96,97)}$

(4) Application of Oil Mist Lubrication Technique ${ }^{97-101)}$

The oil mist lubrication of roll neck bearing started

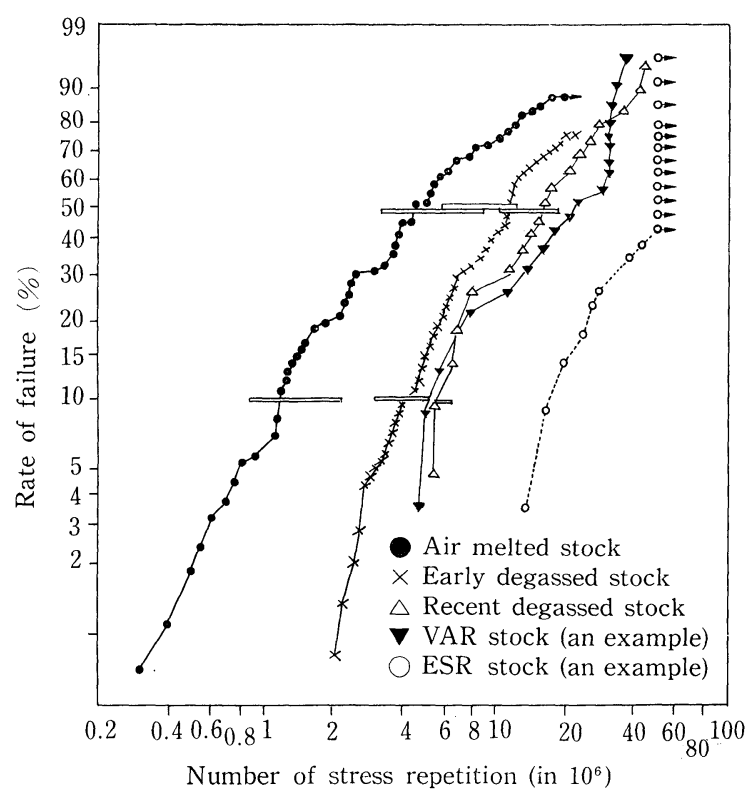

Fig. 51. Roll fatigue lives of steels manufactured by different melting practices.

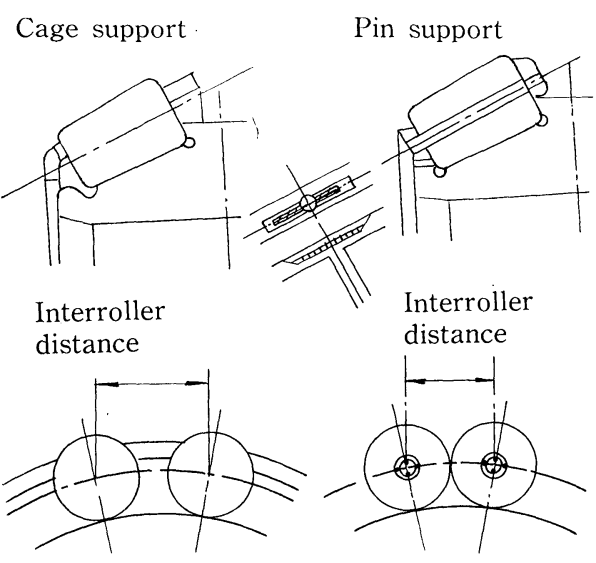

Fig. 52. Comparison between cage support and pin support for roller bearing.
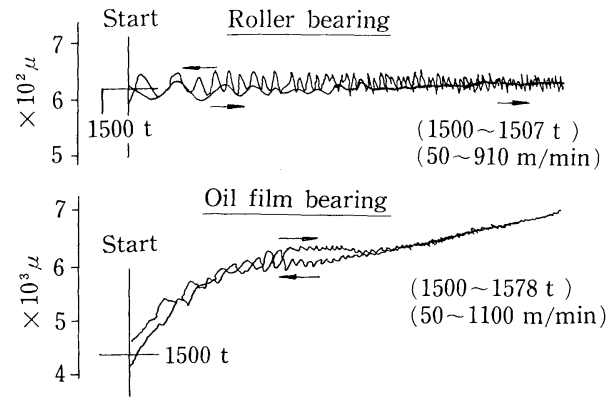

Fig. 53. Changes in oil film thickness due to change in rolling speed for roller bearing and oil film bearing.

again with aluminum rolling mill in 1960s, and in 1967 was applied to skin pass mills of $1000 \mathrm{~m} / \mathrm{min}$ or less. Recently, however, the use is spreading fast so that work roll bearings of cold strip mill and hot strip mill, and also of backup roll bearings, are now mist-lubricated, some of which is for $2500 \mathrm{~m} / \mathrm{min}$.

The benefits of oil mist lubrication is the prevention of oil contamination, simplification of mainte- 
Table 11. Comparison between roller bearing and oil film bearing for backup roll.

\begin{tabular}{|c|c|c|}
\hline & 4 row roller bearing + thrust bearing & Oil film bearing + thrust bearing \\
\hline Type & $850 \phi \times 1.180 \phi \times 800 l \mathrm{~mm}$ & ex. $882.65 \phi \times 637 l \mathrm{~mm}$ \\
\hline Load capacity & $2020 \mathrm{t}$ & $1459 \mathrm{t}$ \\
\hline $\begin{array}{l}\text { Maximum } \\
\text { rolling speed }\end{array}$ & $1600 \mathrm{~m} / \mathrm{min}$ & $2000 \sim 2500 \mathrm{~m} / \mathrm{min}$ \\
\hline $\begin{array}{l}\text { Start-up } \\
\text { characteristics }\end{array}$ & $\begin{array}{l}\text { The starting torque is smaller than that for oil } \\
\text { film bearing. } \\
\text { Can bear full load right after starting. }\end{array}$ & $\begin{array}{l}\text { Load must be increased gradually. } \\
\text { Lower limit speed is } c a .100 \mathrm{~m} / \mathrm{min} \text {. }\end{array}$ \\
\hline Bearing precision & $\begin{array}{l}\text { Radial gap: } 0.2 \sim 0.35 \mathrm{~mm} \\
\text { Radial sway : } 20 \mu \mathrm{m}, \text { max. } \\
\text { Inner ring eccentricity : } 5 \sim 10 \mu \mathrm{m} \text {, min. } \\
\text { Roller-to-roller dimensional difference : } 3 \mu \mathrm{m} \text {, min. }\end{array}$ & ca. $0.8 \mathrm{~mm}$ \\
\hline $\begin{array}{r}\text { Revolution } \\
\text { precision }\end{array}$ & $\begin{array}{l}\text { Depends on fabrication (mostly uneven inner } \\
\text { ring thickness), not on lubricant. } \\
\text { The center line changes by the rolling load due } \\
\text { to elastic deformation by ca. } 0.01 \mathrm{~mm} / \mathrm{t} \text {. } \\
\text { The operational precision is } 10 \sim 20 \mu \mathrm{m} \text {. }\end{array}$ & The operational precision is $10 \sim 40 \mu \mathrm{m}$. \\
\hline $\begin{array}{l}\text { Friction } \\
\quad \text { coefficient }\end{array}$ & $\begin{array}{l}\mu=0.0015 \sim 0.004 \\
\text { Very little change in } \mu .\end{array}$ & $\begin{array}{l}\mu=0.0012 \sim 0.003 \text { (high speed revolution) } \\
\text { Change in } \mu \text { is comparatively large, depending } \\
\text { on revolution, oil viscosity, temperature, etc. }\end{array}$ \\
\hline Service life & $\begin{array}{l}1.5 \text { years as calculated. } \\
3.5 \text { years as estimated. } \\
\text { Recent experiences show the actual life is } 2 \sim 3 \\
\text { times the calculated life. }\end{array}$ & Experienced life 5.0 years. \\
\hline Lubrication & $\begin{array}{l}\text { Oil mist lubrication } \\
\text { Oil viscosity : } 1500 \sim 2000 \mathrm{SSU} \\
\text { Oil consumption }: c a .300 \mathrm{l} / \mathrm{month}\end{array}$ & $\begin{array}{l}\text { Forced circulation lubrication } \\
\text { Oil viscosity : } 800 \sim 1500 \mathrm{SSU} \\
\text { Oil consumption : ca. } 700 \mathrm{l} / \mathrm{month}\end{array}$ \\
\hline
\end{tabular}

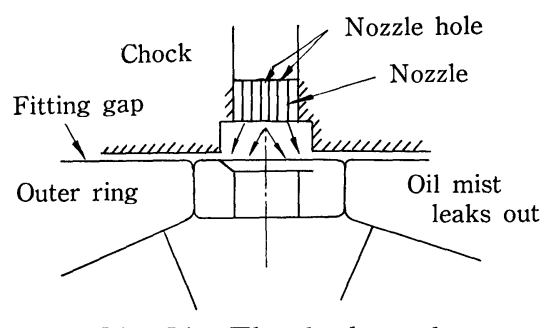

Fig. 54. The chock nozzle.

nance, reduction of lubrication costs, and prolongation of bearing life. Further, to make the oil mist lubrication adaptable to high speed rolling, many improvements have been made.

(i) Improvement in Nozzle Design

Conventionally, the chock nozzle (Fig. 54) was used, but troubles of insufficient lubrication, excessive heating, and seizure of bearing often took place. For those, the distance piece nozzle was introduced (Fig. 55). The temperature rise is compared between the two in Fig. 56.

(ii) Change of Oil Feed

Earlier on, the oil feed was determined on an equation $\mathrm{CFM}=D \cdot R / 20$ (where, CFM: cubic feet per minute; $D$ : the bearing inner diameter; and $R$ : the number of roller rows), but this tended to give insufficient feed rate, so that today it is read $D \cdot R / 5$ to 6 instead of $20 .{ }^{99,100)}$

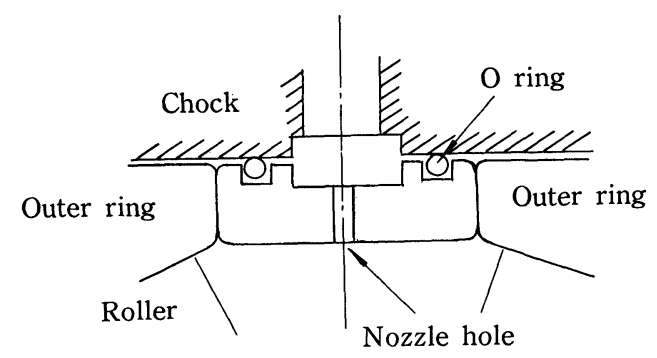

Fig. 55. Distance piece nozzle.

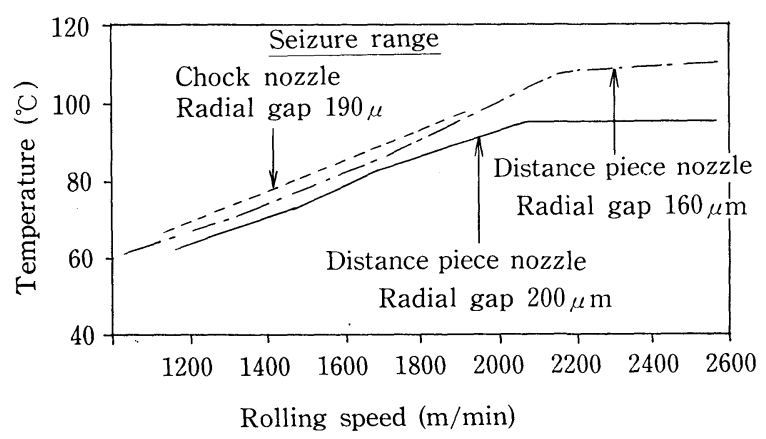

Fig. 56. Change in temperature rise of work roll bearing by changing the bearing design.

(iii) Change of Gap

In the grease lubrication, the gap is set at the lower limit of the $\mathrm{C}_{2}$ gap, but for high speed rolling with mist lubrication, smaller gap tends to give higher 
Table 12. Potential causes for shocks and overloadings in rolling mill.

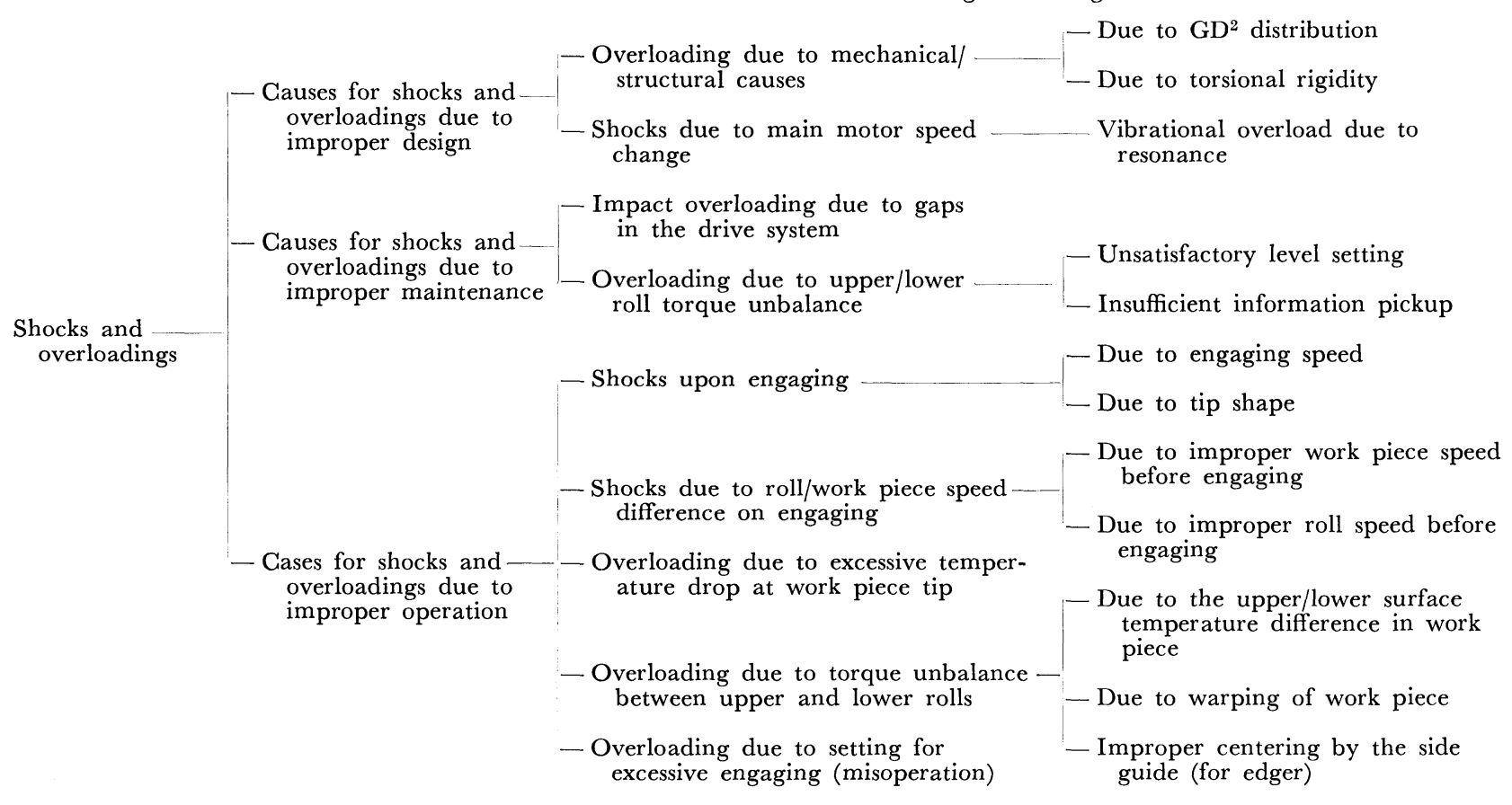

temperature at the bearing (Fig. 56), whereas larger gap results in smaller loading rate and shorter bearing life. Therefore, for high speed rolling, the gap is set in a range of the upper $\mathrm{C}_{2}$ limit and the St gap. ${ }^{98)}$

Other advances of note are the triple-layer film lubrication for the rod mill finishers, the adoption of universal spindle in the mill driver line, and the improvement of the lubricant oils themselves. Further research activities will be directed to the improvement of reliability under high speed rolling and to the problems of change in roll crown due to heating of bearings.

\section{Vibration Analysis of Mill Drive}

As the rolling speed increased, accidents of various parts in the mill drive system, from rolls to main drive motors, getting seriously damaged have progressively increased in number. This phenomenon was particularly noted in the hot working reversing mills. For example, in the advanced mills that were commissioned after about 1970 in this country, especially in the bloomers, cracking of rolls, sprindles, and couplings, or mechanical damages in the main motors, have been reported.

The excessive torque that was the immediate cause of those accidents could have been several times the torque rated for the drive system. It is considered as having been induced in the mass-spring system of the mill drive line, in correspondence with the occurrence of twist vibration due to the shock of engaging the stock. The fast enlargement of capacity and acceleration of speed may have helped this also. ${ }^{102)}$

The analysis of twist vibration phenomenon began with the accidents that had occurred in the main drive motor of a bloomer which was built by an American firm for a certain steel works of Japan in 1960 s. $^{103)}$ First, the drive system was considered to be a rigid body (Table 12), ${ }^{102}$ ) but subsequent study revealed various causes for the occurrence of twist vibrations under impact loads. Among those, the speed of engagement, temperature, shape of the stock, amount of reduction, arrangement of masses and springs along the line, and the backrush hidden in the drive system were suspected as important (Table 12).104)

For the existing mills, the pass schedule, namely, the amount of reduction, speed of engagement, and others, was reviewed to alleviate the impact load, and more careful controlling of steel temperature and elimination of backrush are being practiced. Further, alarm systems that detect the occurrence of excessive torque by directly measuring the axial torque have been commercialized. Also, an appropriate number of stand-by rotors of better load bearing capacity are being prepared for the main drive motor.

More recently, analysis of twist vibration has made a remarkable progress by simultaneously treating the mechanical and the electrical control systems and by considering the effects of nonlinear backrush by the use of fast digital computers. ${ }^{104-110)}$ Results of those studies are being taken in the new operational and maintenance standards by solving the problems of (A) resonance vibration of mechanical and electrical control systems, which is especially important in such fast response mills as the hot strip mill, (B) optimum arrangement of masses and springs along the drive line, and ( $\mathrm{C}$ ) determining the design basis of safety strengths for various components like the rotor or the shear pins.

Future research will be directed to the effects of steel temperature, direction of rolling, and other factors on the twist vibration, and to the abnormal vibration that is considered to be induced when the stock fails to engage or when excessive slipping has 
occurred between roll and stock.

\section{Fabrication Technology}

Of the almost numerous components of a rolling mill, I shall take up only the rolling rolls, the roll stands, and the gears for their recent progress.

\section{Rolling Rolls}

The material of rolling rolls is either cast iron or cast or forged steel, and changes in materials and fabrication methods are summarized in Fig. 57.111-113)

The cast iron rolls have since early times been the chilled or grain rolls cast solid from one heat, but to ensure sound structure and stable hardness the double pour casting method was developed. Further, to improve the roll quality, the composite roll made by the centrifugal double pour method has made fast progress. Today, almost all the hot strip mill work rolls are of this type composite roll. The application of spheroidal graphite cast iron, or the ductile cast iron as is often called, which has a good heat resistivity and toughness, to roll making has also made a remarkable advance, particularly for large rolls. For example, as bloomer roll, the service life of spheroidal graphite cast iron rolls is about three times that of conventional cast steel rolls.

To supplement the cast irons and cast steels, a high carbon cast steel, the adamite, which is intermediary in every respect between the two, was developed in this country about the same time as the introduction of the ductile cast iron. Thanks to its good heat resistivity, outstanding toughness, and small hardness decrease from surface inwards, the admite has found application first to shape mill rougher rolls, then, as its properties improved, to thin gage work rolls. In recent years, further, forged adamite that combines all those features and excellent wear resistivity, as well as much improved toughness, has been commercialized. ${ }^{114)}$

In the field of steel roll making, the double pour method, ${ }^{118)}$ the composite ingot forging method, the surface quench hardening method, ${ }^{115-117)}$ and others have made significant progress, so that many rougher rolls and backup rolls of hot strip mill are made by those methods today. Especially, for the work rolls of cold strip mill, which demand a very high quality, the deep quenching method and the ESR (electroslag remelting) method are being applied. Also, in keeping with the enlargement of mills themselves, technologies of melting, casting, forging, heat treating, and machining have progressed, so that backup rolls of as much as $250 \mathrm{t}$ and work rolls of $65 \mathrm{t}$ are available today.

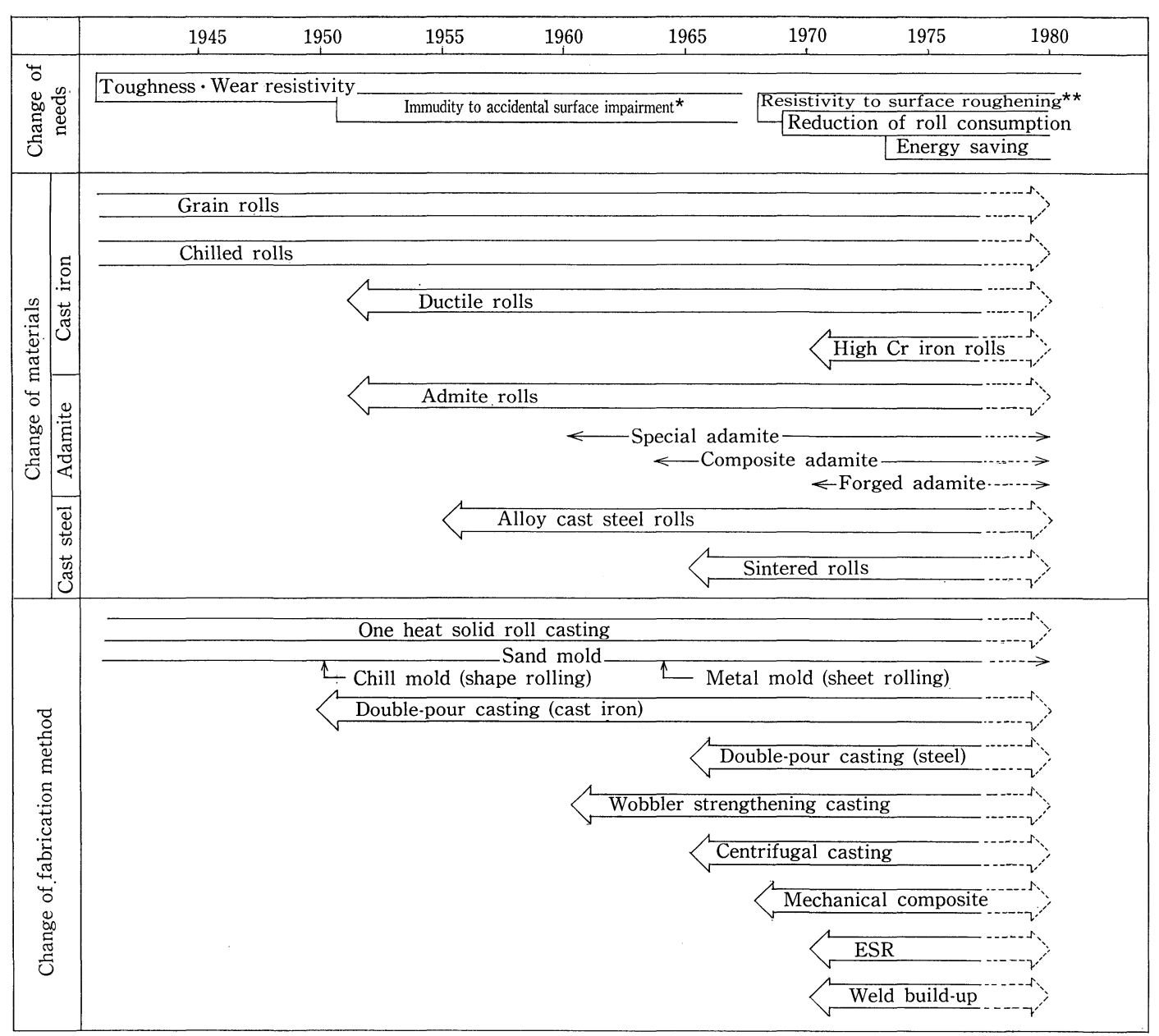

* A property the roll surface not getting damaged even when accidents due to abnormal rolling had occurred.

** Damages to roll surface due to unevenness in profile.

Fig. 57. Changes in demands and corresponding progress made in material and fabrication method for rolling rolls. 
In the following, samples are drawn from the rolls for hot strip mill and cold strip mill.

\section{(1) Rolls for Hot Strip Mill119)}

For the rougher working roll, to satisfy the demand for better resistivity to heat check and to surface roughening, trends are to use high alloy stocks. As for fabrication method, the composite casting method, particularly the one that metallurgically unifies the hard shell with the ductile and tough core by means of centrifugal casting, is the most popular. Also, composite rolls that are made by mechanically assembling the sleeve and the arbor are used. Both have contributed greatly to reducing the per rolled steel tonnage roll consumption. More recent topic is the weld overlaid surface roll, which appears to be promising.

For the finisher work roll, to guard the surface finish and shape of the products, not only the resistivity to wear and surface roughening but immunity from accidental surface impairment-a property that the surface not getting damaged even when mishaps like abnormal rolling had occurred-are important, the latter especially for the rear stages work rolls. For this, rolls of adamite base with structure and chemistry modified according to the rolling conditions are popular for the fore stages, wheras centrifugally cast composite rolls have replaced the double pour high alloy cast iron composite rolls. To meet the demand for harder surface, rolls made by metal mold casting method, surface quench hardened ones, and those of high chromium cast iron with 12 to $20 \% \mathrm{Cr}$ are being examined for early use.

For the backup roll, on the other hand, the surface quench-hardened rolls are becoming standard to ensure good product shape and smooth engaging of work piece.

\section{(2) Rolls for Cold Strip Mill15-120)}

Here, especially for stocks for galvanizing and for very thin gage steels, the demand for surface quality assurance is particularly severe. For this, the resistivity of work rolls to surface roughening is of particular importance, and this means rolls of high surface hardness. This is being satisfied by the induction heating and quenching method coupled with the subzero treatment that ensures twice or more deep hardened zone of what was achievable with conventional straight dip quenching method's 10 to $15 \mathrm{~mm}$. Also, the ESR method ingot making is applied to raise the inner soundness, to increase the service diameter, and to improve the immunity from accidental surface impairment.

\section{(3) Others}

Those fabrication methods mentioned above are being used selectively in accordance with the special needs. One exception is the tungsten carbide sintered rolls that are being used at the wire rods mill finisher blocks.

\section{Fabrication of Roll Stand}

The roll stands are now made from cast steel rather than cast iron, and those that weigh $400 \mathrm{t}$ or more as cast are being manufactured. However, as the electric furnace capacity still remains at a level of $100 \mathrm{t}$ per charge, the holding furnace that also functions as homogenizer of temperature and chemical composition of the heat is generally used to secure the necessary quantity. ${ }^{121}$ ) Further, since the segregation right under the riser became more apparent as the cast became larger, the so-called progressive casting technique, in which the melt to be added through the sprue is controlled chemical compositionwise in accordance with solidification, has contributed greatly to obtaining uniform quality products. ${ }^{122}$ ) Moreover, as a long time is needed from tapping to casting, sliding gate nozzle stopper has been developed to ensure uniform flow rate through the nozzle. ${ }^{122)}$

There has been progress in the mold making also. For example, the sand was improved into the so-called dry sand, in which the proportion of clay is held to less than $3 \%$ to prevent glazing, while the furan, a phenol resin, has been developed to make a selfhardening mold. ${ }^{122,123)}$

In the progress of very large cast articles, the contribution made by the ESW (electroslag welding) method, a Russian invention, cannot be overlooked. Since occurrence of shrinkages and segregations, hence degradation of quality, is inevitable with large castings, building-up of large articles by means of this welding method out of smaller components has made fabrication of very large cast products possible. There is an instance in which a rolling mill stand of $280 \mathrm{t}$ as cast was fashioned from four castings by ESW into a single piece (Fig. 58). ${ }^{124}$ Also, some stands have been fabricated out of heavy plates by ESW.

\section{Fabrication of Gears}

The large main reduction gears were used to be made by casting into a solid one piece, but those very large diameter gears that the enlarged high speed rolling mills wanted could not be made by simple casting. Therefore, after the shrink-fitting method was tried with limited success, the weld building-up method became most popular since 1965. Also, due to the change-over of tooth from cast iron to cast steel, the bending strength was increased by $30 \%$, while the fatigue strength, too, was improved markedly by adopting special steels such as Cr-Mo type or $\mathrm{Ni}-\mathrm{Cr}-\mathrm{Mo}$ type. ${ }^{125)}$

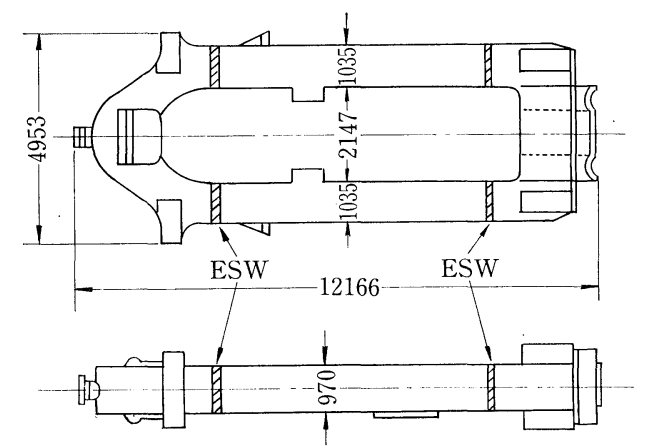

Fig. 58. An example of application of ESW method to fabrication of a heavy plate rougher mill stand. 
Generally, the increase of strength and reduction of size of teeth have been achieved through progress in the heat treatment techniques of tempering, induction quenching, carburization quenching, nitriding, and others. The tempering, which was progressed by using proper alloy steels so as to be capable of hardening to Hs 65 level, is widely employed.

In the induction hardening, as applied on the tooth surface only, residual stress is left at the boundary of hardened zone to be a cause of cracking. ${ }^{126}$ ) Therefore, the all-round hardening method that forms hardened zone even at the tooth root and the tooth-by-tooth progressive hardening method have been developed. The carburization quenching is noted for better bending fatigue strength and wear resistivity owing to the high hardness of over $\mathrm{Hs} 75$ of the carburized zone and to the compressive residual stress induced upon quenching, it is extensively applied to high load carrying gears like pinions. As the mechanical properties depend much on the carbon content of the carburized zone as may be seen in Fig. 59, ${ }^{126)}$ however, the surface carbon content need be well controlled. For this, the gas carburization that gives stable sintering has been developed. The nitriding, on the other hand, would give a rather shallow hardened zone of only $1 \mathrm{~mm}$ or less, even though the hardness could be over Hs 70. For this reason, this method is rarely used for rolling mill gears.

As for the gear cutters, the static rigidity, dynamic rigidity, and thermal rigidity have been improved to meet the required size and precision and to shorten the work time. For the gear cutting tool, particularly that for heavy and high speed cutting work, the multiple teeth hob and the assembled hob of exceptional length were developed and are being used widely today.

In the mean time, the material for hobs, too, were improved. Namely, the high speed steel has been improved for cast structure and toughness by resorting to VAR (vacuum arc remelting) method or the ESR method, ${ }^{128}$ ) while superhard tool made by sintering has made appearance. ${ }^{129)}$ This latter is especially useful for finishing the surface-hardened gears that necessarily contain a large strain. Its merit of reducing the fabrication cost is well noted.

The precision of meshing has become a grave con-

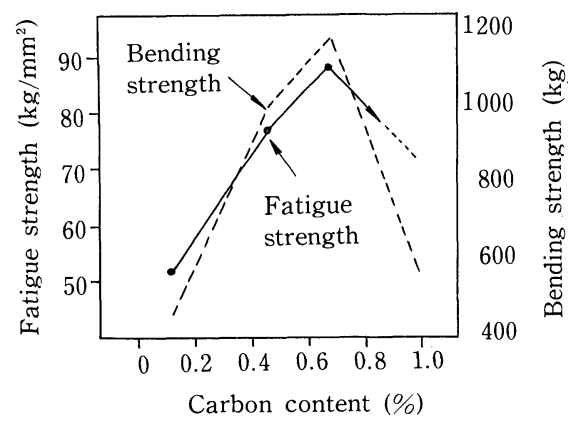

Fig. 59. Relationships among surface carbon content, fatigue strength, and bending strength for a carburizequenched gear tooth. cern, so that in many cases gears are being fabricated in a constant temperature room with its temperature controlled to within $\pm 3{ }^{\circ} \mathrm{C}$. The tooth profile, too, is being improved to raise the strength level, so that, for example, gears with a pressure angle of more than $20 \mathrm{deg}$ by JIS are often found today. Also, the circular profile tooth gear, which is due to M. Novikov, has been empirically proved to possess a bending strength that is 2 to 3 times the normal involute tooth gears. They are being tried on operational rolling mills.

\section{Installation Technology}

The enlargement, acceleration, and demand for higher precision on the part of rolling mill promoted fast progress of installation technology, which has resulted in marked prolongation of equipment life, shortening of work time, and saving of labor. Here, I wish to review the progress achieved in the foundation laying techniques centering on grout and on-site repairing techniques.

(1) Methods of Laying of Load Carrying Foundation

There are methods like (i) by pads, (ii) by pads and grout, (iii) entirely by grout, (iv) by very thick baseplate and chock liner, and (v) entirely by base plate aided by grout, are available. Those methods are all closely related to the progress of grout, such that, for example, the development of no-shrink mortar has made methods (i) and (ii) possible, while the advent of high fluidity, high strength no-shrink grout is the direct cause of (iii) and (v). Although the particulars may differ from a firm to another, the trends are to place importance on the grout.

(2) Grout Materials

The progress in the no-shrink grout materials is shown in Fig. 60. They have been used in the steel works from early times for repair works, but their adoption to regular foundation laying work is since 1965.

The grout materials are classified in Table 13 by their shrink-preventing measures and by the aggregate. Generally, metallic aggregates are used for places that must bear impact or repeated load, but they have been considered inapplicable to where thermal deformation or dry/wet atmosphere is repeated for the fear of metal aggregate getting continually oxidized. This shortcoming has been eliminated recently by some of the metal aggregate grout, which utilize the hydrolysis of cement for shrink prevention. Those are marked out with asterisks in Fig. 60. The resin grout is to be used in a trade-off of its very fast strength development and the high price.

(3) Installation Work

The most important in the grout casting is the controlling of consistency, method of casting, and procedure of curing.

(i) Control of Consistency

The consistency of a grout is determined by the water addition. It is being controlled by means either of the flow table or the $J$ funnel, of which the former is less popular because of difficulty of setting 


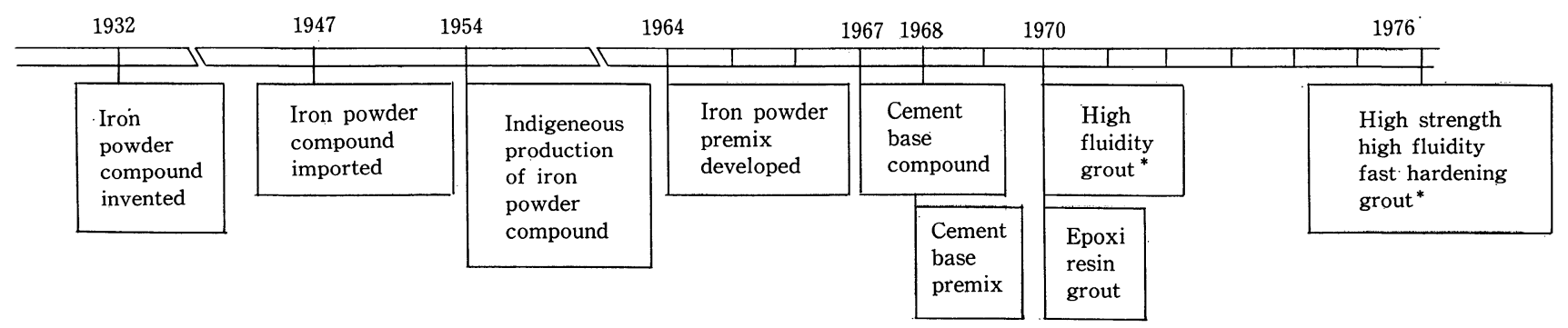

* Grouts that utilize the hydration reaction of cement for counter-contraction.

Fig. 60. Progress of grout material.

Table 13. Kinds of grout materials

\begin{tabular}{|c|c|c}
$\begin{array}{c}\text { Cement } \\
\text { base }\end{array}$ & $\begin{array}{c}\text { Counter-contraction by metal } \\
\text { (iron) powder as aggregate } \\
\text { Counter-contraction by } \\
\text { hydration of cement }\end{array}$ & $\begin{array}{r}\text { Metal } \\
\text { aggregate }\end{array}$ \\
& $-\begin{array}{r}\text { Nonmetallic } \\
\text { aggregate }\end{array}$ \\
- Epoxi resin \\
base & - Entry guide & - Free lime \\
& - Plaster \\
& - Mixed
\end{tabular}

the table straight at the work site, inviting the measurement error to become large. The control index by means of the $\mathrm{J}$ funnel is $10 \pm 3 \mathrm{sec}$ for iron powder type and $8 \pm 2 \mathrm{sec}$ for cement type.

(ii) Casting

Of the two major casting methods, the gravity method and the pressure injection method, the former is the more conventional. Up until about 1970, the use of ordinary tilting mixer or hand mixer to store the grout in a large hopper before casting under natural gravity was general, but the appearance of a special grout mixer has made it possible to cast forcibly even into underneath the large baseplates with an aid of bag pipe method by dividing the foundation into several blocks. On the other hand, the pressure injection, or the pumping, method is gaining popularity since about 1969. As for the pump to be used, the squeeze type is often recommended, because the piston type pump is liable to suck up air into the grout as it is intermittently pumped up.

(iii) Guring

While the workers were yet unaccustomed with no-shrink grout, problems due to unsatisfactory curing like hair cracking or insufficient strength development were not uncommon. For this, procedures involving the wet curing using water flooding or wet rag or the covered curing method, in which the surface is covered with ordinary mortar, have been developed. Also, in cold regions, acceleration curing by heating with radiators or steam, and keeping the work warm by covering with canvas sheets, is often practiced.

\section{On-site Machining}

The purpose of on-site machining being to perform necessary reparing, correction, or restoration works right at the side of the apparatus either to shorten the downtime or to attend to the troubles of large equipment that is nearly impossible to disassemble, it was only those modern and great steel works that were commissioned between 1955 and 1960 that first introduced this on-site machining as a part of daily maintenance work.

(1) On-site Surface Overlay Welding

When a damaged surface is to be machined, it has often to be rebuilt by overlay welding. In this case, because of limited spatial and time allowances, simplified procedure is often adopted, though the work quality has to be high. That is, where at a regular welding shop a series of procedures comprising pretreatment of the hardened zone, removal of the defects, preheating, overlay welding, postheating, stress relief annealing, and inspection would have to be gone through, at the site, postheating and stress relief annealing might be omitted whenever a weldment that is close in quality to regularly made weldment could be obtained. Points of technical merits are listed in Table 14.

\section{(2) On-site Machining Apparatuses}

The machine tools that are to do the on-site machining are subjected to severe restrictions in the size and shape. Further, they are all individually special as to be able to meet the highly diversified needs. Therefore, those machines that are available on market are rarely fit for the service. Thus, as many machines of similar duties, and as much of their parts as possible, should be designed for ready interchange, but this must be done by individual steel works. Table 15 summarizes recent repair machining successfully conducted in a certain steel works.

\section{Future Prospects of Rolling Equipment}

It is generally believed that the future of rolling lies in high quality products and energy saving operation rather than in mass production. New equipment and new controlling technology are in the offing today in this line. Here, I like to examine several of those that are worthy of particular notice.

\section{Low Temperature Extraction}

The low temperature extraction practice is becoming widely popular for the merit of lowering the fuel rate at the reheating furnace and to reduce the scale loss. This practice is most positively adopted in the hot strip mill.

\section{Effects of Low Temperature Extraction}

By lowering the temperature of extracting the 
Table 14. Points of technical care for simplified on-site surface building-up welding practice.

\begin{tabular}{c|c}
\hline \multicolumn{1}{c|}{ Points of care } & Purposes and effects \\
\hline $\begin{array}{c}\text { Use of moisture non- } \\
\text { absorbing, very low } \\
\text { hydrogen electrodes }\end{array}$ & $\begin{array}{c}\text { As the rate of moisture absorption of re-dried electrodes is very low, they bear a long time of } \\
\text { welding. Also their very low hydrogen content ensures immunity from hydrogen embrit- } \\
\text { tlement and delayed cracking. }\end{array}$ \\
\hline $\begin{array}{c}\text { Auxiliary use of high } \\
\text { ductiliy and high } \\
\text { toughness electrodes }\end{array}$ & $\begin{array}{c}\text { By applying these electrodes to primary overlaying to edges and corners and to bead ends, } \\
\text { relaxation of weld stress, prevention of crack propagation, and improvement in fatigue } \\
\text { strength are achieved. }\end{array}$ \\
\hline Order, direction, layering & $\begin{array}{c}\text { Welding procedures like stepping stone advance, cascade overlaying, two metals alternative, } \\
\text { oblique progression, crater merging, orthogonal progression, and backward progression } \\
\text { should be properly employed to the purposes such as stress relaxation, prevention of crack } \\
\text { propagation, prevention of spalling, prevention of strain. }\end{array}$ \\
\hline Peening & Effective for weld stress relaxation, prevention of strain, improvement of structure. \\
\hline
\end{tabular}

Table 15. Actual examples of on-site machining.

\begin{tabular}{|c|c|c|}
\hline \multirow[t]{2}{*}{ Milling } & Vertical face & $\begin{array}{l}\text { Housing wind face of bloomer, hot strip, plate mills ; Wind face of slab shear; } \\
\text { Attach face of shear knife; Flange face of BF hot blast valve; Trunion block } \\
\text { of BOF }\end{array}$ \\
\hline & Horizontal face & $\begin{array}{l}\text { Housing wind base of various mills; Attach face of shear knife; Attach face of } \\
\text { feed roller chock; Various motor bases; Sole plates; BF carbon bricks }\end{array}$ \\
\hline Boring & & Feed roller bores; Table roller bores; Reduction gear bearing cavities \\
\hline Drilling & $\begin{array}{l}\text { Drilling, tapping, } \\
\text { reamering }\end{array}$ & $\begin{array}{l}\text { Attach holes for mill housing liner; Axis hole for BOF tilting gear; Holes for } \\
\text { tapered pin; Holes for in-pouring of BF shell milk }\end{array}$ \\
\hline \multirow[t]{2}{*}{$\begin{array}{l}\text { Peripheral } \\
\text { machining }\end{array}$} & Work rotating & $\begin{array}{l}\text { Large motors; Generator commutators; Slip rings; Tires of sinter drum } \\
\text { mixer; Support rollers of rotary kiln }\end{array}$ \\
\hline & Tool rotating & $\begin{array}{l}\text { Flying shear crank pin; Drive axel of pinch roller reduction gear; BOF tilting } \\
\text { cylinder bottom; Motor shaft of hydro conecrasher }\end{array}$ \\
\hline Slotting & & Cotter slots; Key slots \\
\hline
\end{tabular}

slab out of reheating furnace, the fuel rate of the furnace is effectively cut down, but the resistance of the stock to deformation is raised, making the power rate of the rolling mill increased. As may be seen in Fig. 61, however, the effects of lowered fuel rate are larger than the latter, ${ }^{\mathbf{1 3 0}}$ ) and adding to this, there is a merit due to decreased scale thickness as shown in Fig. 62.135) Thus, the total merit is definitely for the low temperature extraction practice.

\section{Problems of Low Temperature Extraction and Countermeasures}

The major problems in the low temperature extraction practice are the difficulty of securing high enough finishing temperature, fluctuations in the strip width and thickness, and the roughening of surface. Those are being countered to by individual mills in accordance with their peculiarities.

(1) Securing of Finishing Temperature

When the formability of the finished products is considered, the temperature at the delivery end of the finisher mills need be kept to higher than the $A_{\mathrm{r} 3}$ transformation point. The lowered extraction temperature makes this difficult. Several of the countermeasures taken today are as follows:

(i) Provision of Side Heating Burners

As the temperature drop is greater at the sides than at the center of plate, oxygen burners are provided at the entry end of the finisher train to reheat the both sides. ${ }^{132}$ )

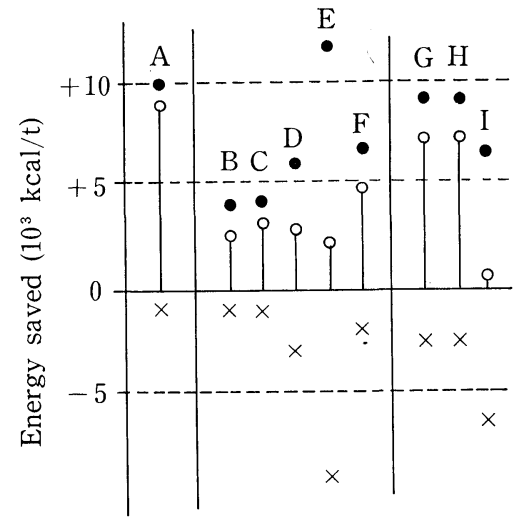

- Fuel rate

$\times$ Power rate (at $2450 \mathrm{kcal} / \mathrm{kWh}$ )

Net gain

The determination of temperature is by the furnace for case A, by the extraction temperature for cases $\mathrm{B}$ to $\mathrm{F}$, and by the rougher delivery temperature for cases $\mathrm{G}, \mathrm{H}$, and $\mathrm{I}$.

Fig. 61. An example of effects for every $10^{\circ} \mathrm{G}$ of low temperature extraction.

(ii) Provision of Adiabatic Cover

A covering that functions to keep the stock warm or even positively reheat it, the so-called adiabatic cover, is provided on the roller table between the rougher train and the finisher train. ${ }^{133}$ ) 


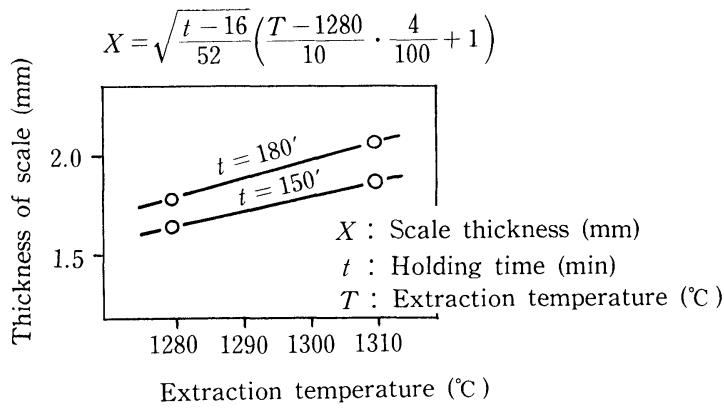

Fig. 62. Relations between thickness of scale and extraction temperature.

(iii) Thickening of Slab

The finishing temperature may be raised by 4 to $5{ }^{\circ} \mathrm{C}$ by increasing the finisher entry thickness of the steel by $1 \mathrm{~mm}$. This can be taken advantage of by strengthening the crop shear. Since this practice results in increased crop loss, however, the thickness increase of the stock must be carefully determined on a trade-off with the merits of fuel saving and reduced scale loss.

(iv) Strengthening of Main Motor for Rougher

By increasing the power of the main motor of the rougher, thus by shortening the rolling time, the temperature drop can be reduced substantially. ${ }^{131}$ )

(v) Acceleration of Finish Rolling

By raising the initial rolling speed and the acceleration rate in the finisher train, the temperature drop can be controlled.

(2) Fluctuations in Plate Thickness and Width

In the low temperature extraction, the amount of skid mark tends to increase, which affects adversely the precision of strip gage and width. The countermeasures being taken are as follows:

(i) Improvement in Skid Button Attachment

The skid buttons are now fixed to the skid pipe through intermediary support rather than being welded directly, as shown in Fig. 63.134) Also, skid pipe itself is designed to go zigzagging or obliquely through the uniform temperature zone. Those proved to be effective to cut down the skid marking.

(ii) Adoption of $\mathrm{AGG}$ and $\mathrm{AWG}$

The use of AGG (automatic gage control) is already universal, and the AWG (automatic width control) has begun to be introduced.

(3) Surface Condition

As the relation between the temperature of steel at the rougher train delivery and the rate of occurrence of defects due to scale is as shown in Fig. 64, ${ }^{131}$ ) it is generally considered that $1000^{\circ} \mathrm{C}$ is the lower limit for the low temperature extraction. A breakthrough here, and an immediate advance in the low temperature extraction practice may be seen.

\section{Hot Direct Rolling and Hot Charge Rolling}

Ordinarily, the slabs and billets that came through the blooming mill are once cooled for removal of defects and for adjustment of rolling timing, then reheated for further rolling. This necessitates an

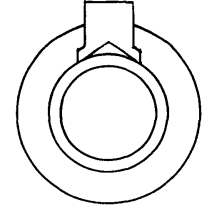

(a) Old design

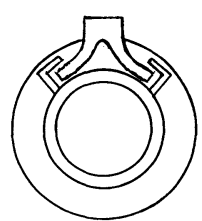

(b) Improved design
Fig. 63. Improvement in the skid button design.

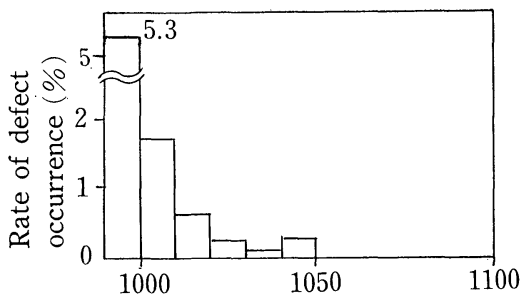

Rougher delivery temperature $\left({ }^{\circ} \mathrm{C}\right)$

Fig. 64. Relation between the slab temperature at rougher delivery and the rate of occurrence of defects due to scale.

energy as much as one half or more of the entire energy consumed in the hot rolling plant. Therefore, the hot direct rolling (HDR), in which the work stock is sent to the products rolling shop directly from the blooming shop without once cooled, has long been contemplated. Because of problems in the quality of the stock, temperature for product rolling, and in the work schedule controlling system from steelmaking to rolling, however, it was not until 1973 that each steel producer began tackling this matter in the earnest. Thereafter progress was fast, and today this practice is spreading widely centering on the hot strip mill line. The procedure of hot direct rolling is shown in Fig. 65 in comparison with conventional process, and the state of adoption in this country's hot strip mills is illustrated in Fig. 66.135)

It is to be appreciated that the advantage of hot direct rolling does not stop at saving the reheating furnace fuel. Actually, there are many other benefits, among which forestalling of occurrence of primary scale, which means improving the product yield, reducing of cost by simplifying the work procedure, shortening of delivery, rationalizing of rolling timing by removing restrictions imposed by the reheating schedule, and hence increasing of productivity, may be noted.

There are several problems assocated with it, however. The major ones are the treatment of surface defects and the temperature control.

(1) Surface Defects

Conventionally rolled slabs often come up with defects that become detrimental to the finally rolled products, such as scabs, surface cracks, and chafes. To prevent those from occurring, carefully controlled ingot casting, underevaluating the mold service life, severe control of chemistry, coating of inner side of mold, ${ }^{135)}$ and use of improved tong punch $^{\mathbf{1 3 6})}$ are commonly practiced. In particular, method of blow coating of the mold inner walls with 
resin is known to be effective against scabs, so that a special machine has been commercialized.

To improve the hot scarfing, on the other hand, various powders and techniques like tapered scarfing or return scarfing are being employed. To overcome the human limitation in detecting hot the defects, further, an automatic hot defect finder has been devised. ${ }^{137)}$ This machine surveys the surface of a slab after the secondary scale has been removed and detects flaws for their positions and size by means of an optoelectronic detector on the relative strength of radiation energy against that of steel matrix. An automatic hot spot scarfer to work on the information

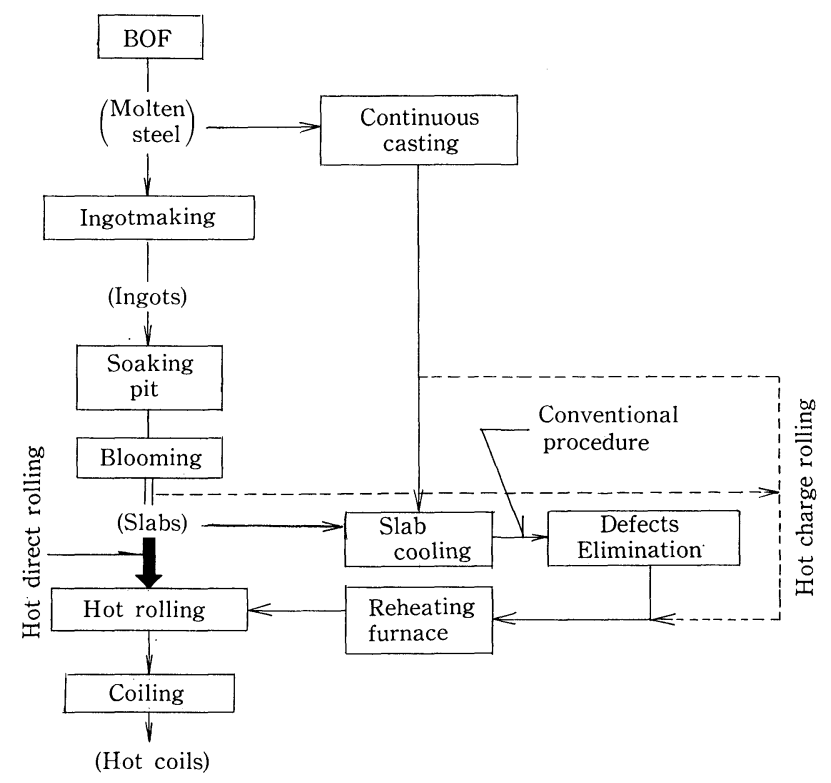

Fig. 65. The hot direct rolling and the hot charge rolling vs. conventional procedure. supplied by this detector is under development. Similar machines are expected to follow suit soon.

(2) Temperature Control

The change in the surface temperature through the hot direct rolling process is shown in Fig. 67. It will be seen that the self-reheating phenomenon that takes place when the slab is given a substantial reduction is taken advantage of. For this, controlling of track time and controlling of combustion at the soaking pit need be strengthened.

Yet, even if the finishing temperature is thus ensured, because rolling necessarily takes a long time, some dropping of temperature at the either edge is inevitable. To counter this, provision of lateral temperature distribution detector, ${ }^{138}$ ) of edge heating oxygen torches at the entry end of the finisher train, ${ }^{139}$ ) or of a warming furnace or an adiabatic cover is common. In keeping with those devices, the roller table and the side guides are being improved by providing cooling means. ${ }^{140}$ ) The progress of those apparatuses that keep the work stock warm will be fast.

\section{Hot Charge Rolling}

Another way to save energy cost at the reheating furnace is to charge the continuously cast slabs directly into the reheating furnace while they are still hot. This practice (HCR) is also gaining popularity as well as the hot direct rolling as may be seen in Figs. 65 and 66.

In the hot strip mill line, the reduction of fuel rate is exemplified in Fig. 68.135) The effect is naturally the greater, the higher the charging temperature, and it amounts to $60000 \mathrm{kcal} / \mathrm{t}$ by $500{ }^{\circ} \mathrm{C}$ charging.

To enjoy the advantages of hot charge rolling further, the time needed from tapping of steel to

\begin{tabular}{|c|c|c|c|c|c|}
\hline \multirow{2}{*}{ Mill } & $\begin{array}{l}\text { Fuel Rate } \\
\left(10^{4} \mathrm{kcal} / \mathrm{t}\right)\end{array}$ & $\begin{array}{c}\text { Degree of HDR } \\
\text { practiced }(\%)\end{array}$ & $\begin{array}{c}\text { Rate of } \\
\text { HDR }\end{array}$ & $\begin{array}{c}\text { Degree of HCR } \\
\text { practiced }(\%)\end{array}$ & \multirow{2}{*}{$\begin{array}{c}\text { Rate of } \\
\text { HCR } \\
(t / \text { month })\end{array}$} \\
\hline & $\begin{array}{llll}10 & 20 & 30 & 40 \\
\end{array}$ & $\begin{array}{lllll}10 & 20 & 30 & 40 & 50 \\
\end{array}$ & (t/month) & $\begin{array}{lll}10 & 20 & 30 \\
\end{array}$ & \\
\hline A & $\square 0.0$ & Under. modification & & I 0.4 & 200 \\
\hline B & $\square 34.1$ & & & ] 3 & 10000 \\
\hline $\mathrm{C}$ & $\square 29.7$ & $\square 22$ & 65000 & & \\
\hline $\mathrm{D}$ & $\square 21.7$ & $\square 44$ & 64500 & & \\
\hline $\mathrm{E}$ & 38.0 & & & $\square 5$ & 7000 \\
\hline $\mathrm{F}$ & $\square 38.3$ & & & 1 & 1530 \\
\hline G & $\square 29.7$ & & & $\square \quad 18$ & 70000 \\
\hline $\mathrm{H}$ & $\square 31.7$ & $\square 12$ & 30000 & Under testing & \\
\hline I & 40.2 & & & ए 11 & 10000 \\
\hline $\mathrm{J}$ & $\square 33.8$ & $\square 14$ & 35000 & $\begin{array}{ll} & 18 \\
\end{array}$ & 45000 \\
\hline K & — 33.3 & & & $\begin{array}{ll}\square & \\
\end{array}$ & 40000 \\
\hline $\mathrm{L}$ & 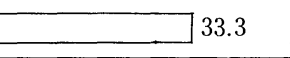 & $\square 12$ & 35000 & $\square 20$ & 60000 \\
\hline M & $\square 0.2$ & 22 & 35000 & Under testing & \\
\hline $\mathrm{N}$ & $\square 33.0$ & $\square 8$ & 17600 & & \\
\hline
\end{tabular}

Fig. 66. National results of practicing HDR and HCR in May through July, 1978. 

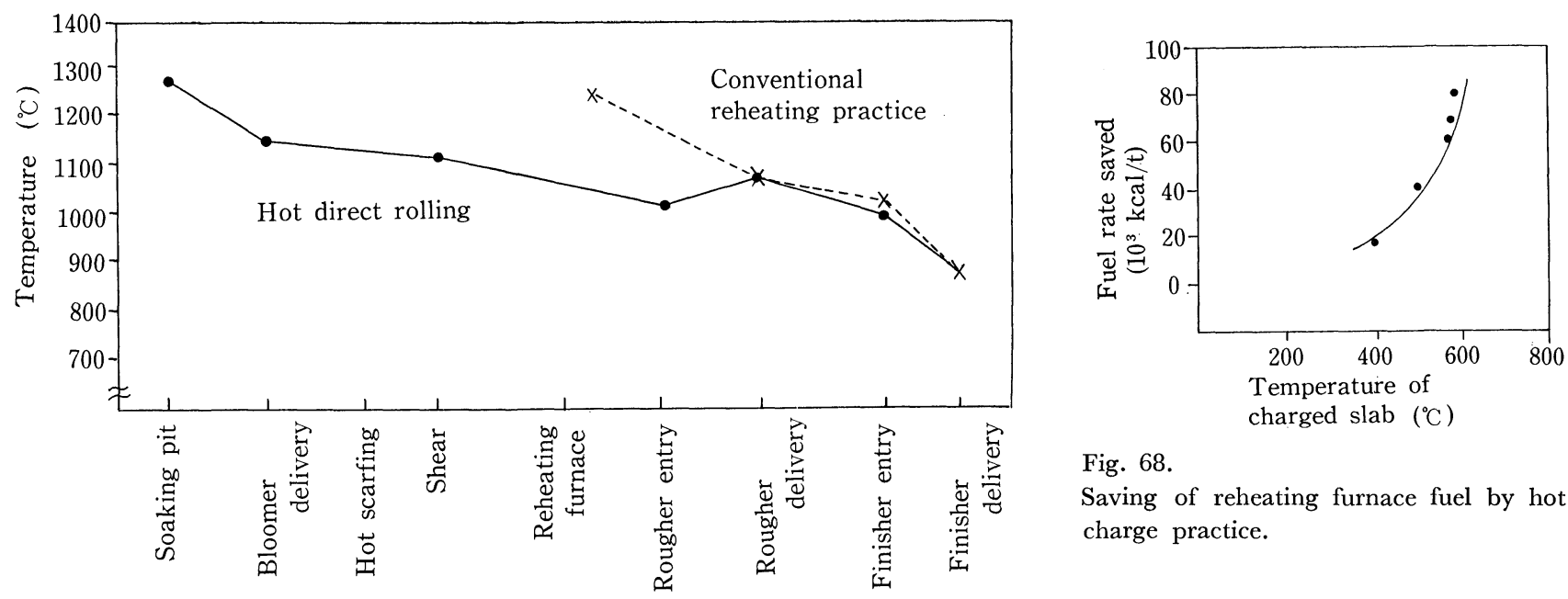

Fig. 67. An example of change in work piece temperature during hot direct rolling.

Fig. 68 .

Saving of reheating furnace fuel by hot charge practice.

charging of slabs into the reheating furnace should be kept as short as possible. For this, development of an optimum command system and improvement of slab quality are necessary. Besides, the need of hot defect detectors, automatic hot scarfers, and reheating furnace automatic combustion control (ACG) is obvious. Those are essentially of the same requirement as for the hot direct rolling.

\section{Shape Control and Plate Crown Control}

As the unsatisfactory shape is a result of nonuniform reduction distribution across the breadth of the plate, the shape control and the plate crown control are inseparable propositions.

In the shape control, a combination of presetting and feed-back control is generally considered, though emphasis is placed on the former for heavy plate rolling, while it is on the latter for cold rolling. For the presetting, simplified model simulators that predict the chronological changes in the roll profile due to elastic deformation, ${ }^{141)}$ wearing, ${ }^{142)}$ or thermal crown ${ }^{143)}$ are available. For the feed-back control, on the other hand, coefficients describing the effects of the controlled, such as the roll bending and the roll coolant, on the shape change have been reported, ${ }^{144)}$ and also an empirical formula that quantitatively relates the changes in the plate crown to those in the shape has been developed. ${ }^{145)}$

Besides those softwares, various shapemeters are available to meet the special needs of each rolling line. ${ }^{146)}$ For example, for plate rolling, an optical shapemeter has been commercialized for some time.

For cold rolling, on the other hand, methods to detect the tension at given points along the width direction of the plate are more popular because here the defective shape tends to be clouded out under the effects of tension. Of those, a method that detects the deflection of plate given rise to by externally applied known strength magnetic field, the one in which the deflector is an air jet, one that employs divided roll to measure the contact pressure distribution, and one that detects the change of permeability as a function of tension are commercialized.

The trouble is that almost all those shapemeters remain today capable of indicating only the pattern for the operator. But with the advent of softwares, on-line computer controlling is expected to become possible within two or three years of time.

As for the corrective means of defective shape, besides the roll bender, which already has a long successful history but is known to be subjected to limitations coming from the rigidity of the roll itself and from the backup rolls when applied to a work roll, the zone control of roll coolant and the anticipatory roll heating method are being employed. More recent advances in this field are the 6-high mill,

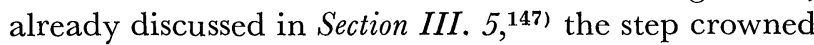
roll ${ }^{148,149)}$ in which either the backup roll or the work roll is given a stepwise crown, and the PV rolling ${ }^{150,160}$ to be discussed a little later. The first two are to alleviate the restrictions imposed on the work roll by the backup roll to increase the effect of roll bending action, whereas the third is to try to free the work roll from the effects of both the backup roll and the work stock. Against those, the one that is on the straight extention of conventional roll bending notion is the double chock bending method, in which an appropriate number of hydraulic cylinders are provided along the length of the chock to give rise to a wider range of bent profilemaking under a given roll balance force. ${ }^{151)}$

Finally, whatever the method, the plate crown control will become not good enough soon if remained controlling the center crown only, for the edge drop should be taken care of at the same time. This is because that nowadays sales contracts are being signed on the TMW (theoretical minimum weight) basis for coils as well as for sheets and plates, and edge drop with its rapid loss of thickness at the edges affects the yield adversely.

For this, theoretical analysis of edge drop formation, which involves both the ordinary roll deformation and the three-dimensional deformation of the work stock, ${ }^{152)}$ as well as empirical formulation studies ${ }^{153}$ ) are being conducted. As for the equipment to counter this shortness, the 6-high mill, the step crowned roll mill, and the PV rolling method all appear to be promising. 


\section{New Rolling Methods}

Here, several methods and apparatuses that are under actual development will be mentioned.

\section{Continuous Casting-and-Rolling of Steel}

The continuous casting-and-rolling of steel, in which the steel is continuously cast, and, without interruption, continuously rolled to the final gage, is drawing much attention in certain quarters for its obvious advantages, and a good number of patents are being applied for. ${ }^{154-156)}$ However, none of the existing methods that are known to be successful for copper or aluminum, namely, the Propelti method, the Hazellet method, and the Hunter method, ${ }^{154)}$ appear to be directly applicable to steel. Figure 69 illustrates the Hazellet system for aluminum.

\section{Width-killing Rolling and Automatic Width Control}

The less frequent the change of slab width, the better is the productivity. For this purpose, certain steel firms have equipped themselves with a sizing mill consisting of several stands, each of which conducts either the plane, or the ordinary, rolling or the vertical, or the width-killing, rolling, right after the continuous casting line. In view of capital cost and productivity, however, the sizing should better be conducted at the hot strip mill rougher train rather than at the continuous casting line.

The benefits of sizing lies in providing a wide range of widths out of slabs of a given dimension, but the reduction of width, which is achieved by the pair of edger rolls, can lead to formation of excessive dog bone, which in turn can be a cause of uneven spreading of plate and of fish tail. On the other hand, the use of grooved roll instead of flat roll for the edger is known to allow greater engaging by enlarging the feed angle, resulting less lateral shrinkage or spring back. ${ }^{155-157)}$

For controlling the width fluctuation, not only in the case of the sizing rolling mentioned above but in ordinary slab rolling, where uneven width due to skid marking is often inevitable, the AWC (automatic width control) is being tried. In this method, the feed-forward controlling is common. Here, either the output of the widthmeter or the opening of the edger rolls is memorized together with the load changes along the length running stock to control the edger opening of the subsequent pass. ${ }^{158)}$

In the hot strip mill, the fluctuation in width of hot coil can arise due to fluctuations in the tension in the finisher train. To minimize this tension fluctuation, new type looper has been devised, ${ }^{131)}$ and more recently a method that attempts at positively controlling the strip width by utilizing the looper tension is being developed. ${ }^{159)}$

\section{Differential (PV) Rolling}

In conventional rolling, the direction of the shearing stress is reversed across the neutral point, and the stresses are symmetrical about the horizontal plane. In the differential rolling, known as the PV (Prokatka Volochenie) rolling, on the contrary, as the upper roll is driven at a speed of $V_{1}$, while the lower at $V_{0}$, namely at a different speed, the work stock, which is being reduced under an externally applied tension, is in effect being continually braked. The result is that the neutral points $\mathcal{N}_{1}$ and $\mathcal{N}_{0}$ are both excluded out of the material to find themselves respectively at the entry and at the delivery ends. This state of affairs is shown in Fig. 70.

This means that the shear stresses acting across the horizontal plane are now cancelled each other, so that the rolling pressure distribution beccomes as shown in Fig. 71, where the absence of the friction hill is to be noted. That is to say, now the rolling pressure distribution is approximately that for solely due to the deformation resistance of the stock itself, meaning that rolling can be performed at a considerably reduced load. ${ }^{\mathbf{1 6 0})}$

Actually, there has been an instance where in an ordinary hot strip mill the upper working rolls of $F_{3}$ to $F_{6}$ were made smaller and only the lower rolls were driven, and it was observed that the rolling load was decreased significantly. ${ }^{161)}$ This is believed to owe in part to the small diameter roll and in another

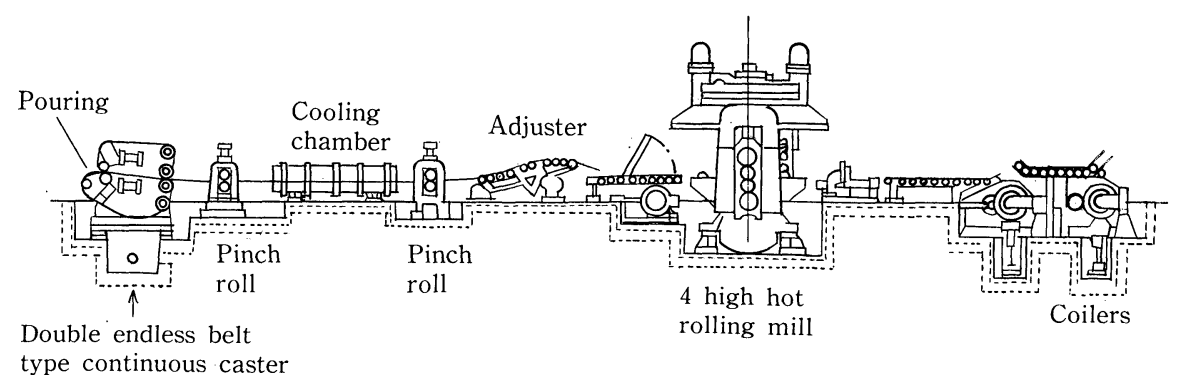

Fig. 69.

The Hazelett fully continuous casting rolling line.

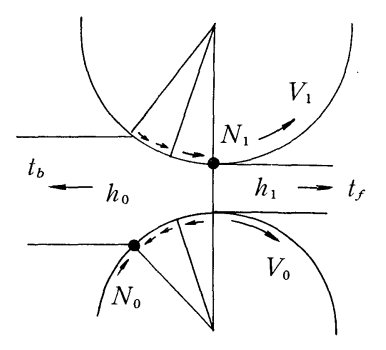

Fig. 70. Principle of PV rolling.

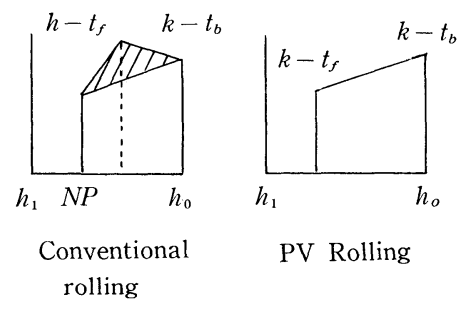

Fig. 71. Pressure distribution during rolling. 
part to the partial PV effect.

\section{New Special Rolling Mills}

The CBS (contact bend stretch) method (Fig. 72), ${ }^{162}$ ) the pendulum mill (Fig. 73), ${ }^{\mathbf{1 6 3}, 164)}$ the reciprocating mill (Fig. 74), ${ }^{165)}$ and the MKW (Mehrwalzen Kalt Walzwerk) mill (Fig. 75) ${ }^{166}$ ) are the ones that appear to be promising. Particularly, the fact that the MKW mill, even though its working principle cannot be called very new, has been commercialized as a tandem mill is worth a special notice.

\section{Skin Pass Rolling with Variable Grown Rolls}

When shape correction is intended by skin pass rolling, the roll profile need be adjusted in accordance with the crown and the flatness of incoming plate as

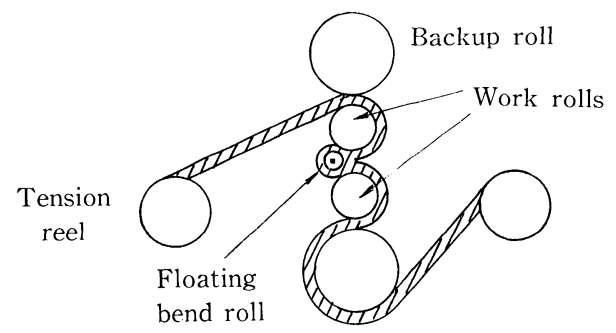

Fig. 72. The GBS rolling mill.

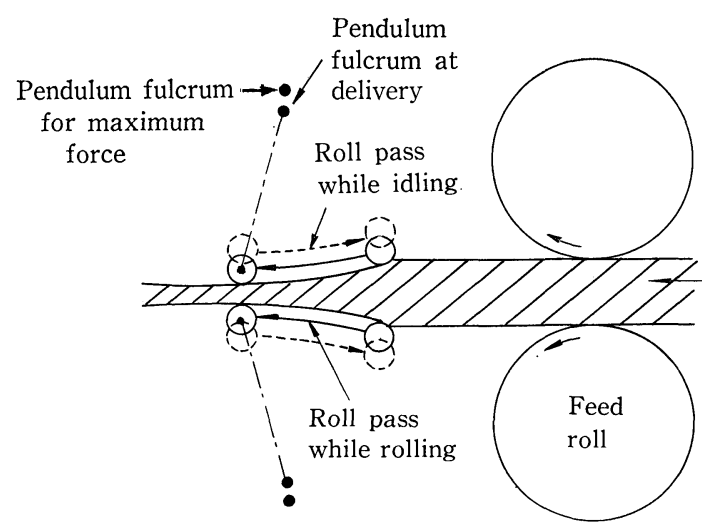

Fig. 73. The pendulum rolling mill.

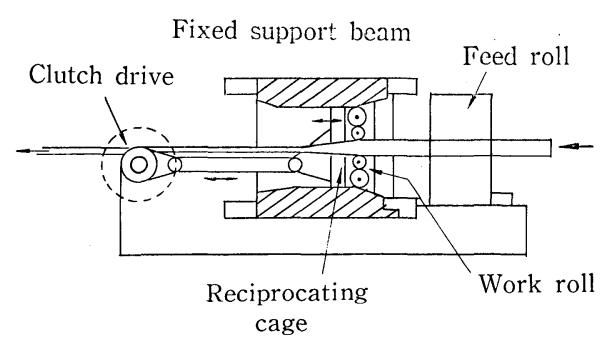

Fig. 74. The reciprocation rolling mill.

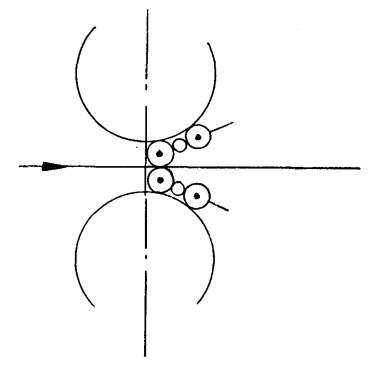

Fig. 75. The MKW rolling mill. well as the rolling load. This cannot be done well by ordinary roll bending alone, and to overcome this difficulty, the VG (variable crown) roll has been developed.

As may be seen in Fig. 76, this roll is a sleeved hollow roll into which oil is forced to change the crown as desired. ${ }^{167)}$

\section{Press-piercing Seamless Pipe Rolling}

A new type pipe making mill, known as the PPM (press-piercing mill), which may eventually replace the old Mannesmann, has been developed. In this method, the material is a squarish continuously cast bloom, which is forced into the mill from the entry side. The force pushing the bloom against the piercing plug and the thrust coming from the circular caliber rolls are utilized to make seamless pipe of high dimensional precision. This is shown in Fig. 77.

\section{Planetary Cross Rolling Mill}

With this mill, which is, as may be seen in Fig. 78 , composed of three conical rolls arranged $120 \mathrm{deg}$ apart, a mechanism to make the rolls revolve around a common center, and another mechanism that drives individual rolls, is said to be able to reduce round or

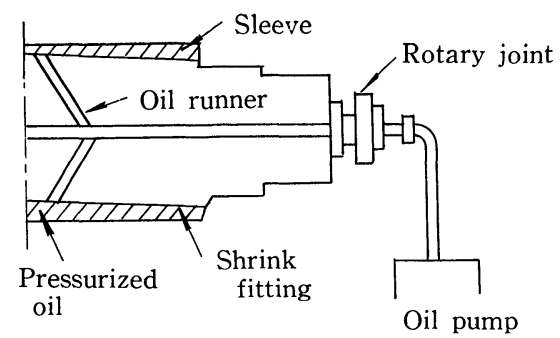

Fig. 76. The VG (variable crown) soft roll.

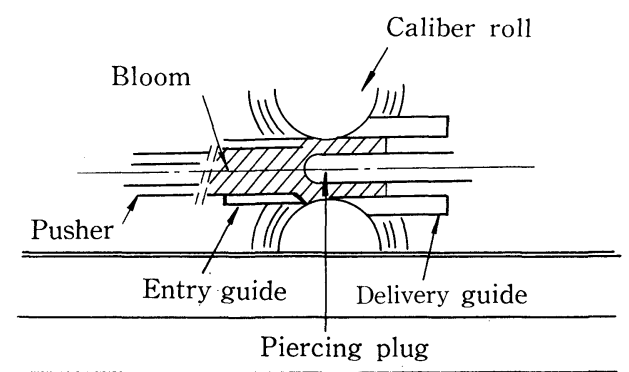

Fig. 77. The press-piercing mill (PPM).

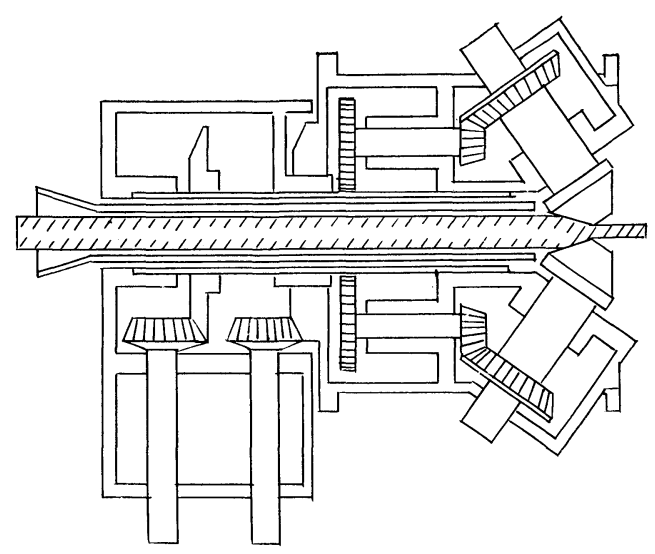

Fig. 78. The planetary cross rolling mill. 
octagonal bar of mild or alloy steels by about $85 \%$ in the areal reduction. ${ }^{9,169)}$ As the claimed performance is equivalent to what is being achieved now by six or seven stands, this mill may merit a special notice, too.

\section{Concluding Remarks}

In the above, I have summarized the status quo of the progress achieved in the rolling equipment technology. Because of limitation in the time and space, however, many interesting topics had to be left out altogether. Yet, I hope that I have shown how the old objectives of advancement, namely, untiring pursuit of productivity through enlargement of mill, increase of rolling speed, concatenation of processes and mills, and automation, are being modified to suit to the pursuit of quality rather than quantity. And those various technologies that have been developed in various fields in support of the rolling technology will again be mobilized to further this end, but any technologies that we may develop will be appreciated on one and the same basis, which is economy.

\section{Acknowledgements}

On concluding my lecture, I would like to express my gratitude to my fellow members of the Rolling Mill Engineering Subcommittee, Joint Research Society of ISIJ as well as to the member firms that freely contributed factual data for me.

\section{REFERENCES}

64) Fujii: The 9th IBM Plant MIS Symposium, (1977).

65) Yamamoto and Kamata: J. Japan Soc. Mech. Eng., 81 (1978), 112-117.

66) ex., Shida: J. Japan Soc. Tech. Plasticity, 19 (1968), 127132 .

67) Shiraiwa: Tetsu-to-Hagané, 59 (1973), 659.

68) Final Report by the Radiation Pyrometer Subcomm. to the 54th Instrumentation Comm., Joint Research Soc., ISIJ, (1973).

69) Final Report by the X-ray Gagemeter Subcomm. to the 51st Instrumentation Comm., ISIJ, (1972).

70) Kawasaki Steel Corp.: Report to the 61st Instrumentation Comm., ISIJ, (1975).

71) Nippon Steel Corp.: Report to the 51st Instrumentation Comm., ISIJ, (1972).

72) Sumitomo Metal Industries, Ltd.: Report on Non-contact Speedometer to the 51st Instrumentation Comm., ISIJ, (1972).

73) Ohshima et al.: Tetsu-to-Hagané, 59 (1973), 604-606.

74) Kawasaki Steel Corp.: Report to the 63rd Instrumentation Comm., ISIJ, (1976).

75) Recent Development of Equipment and Operational Technology of Hot Strip Mills in Japan, ISIJ, Tokyo, (1976), 230-246.

76) Wilmotte et al.: UN ECE Seminar, (1978).

77) Kubota: Recent Development of Equipment and Operational Technology of Cold Strip Mills in Japan, ISIJ, Tokyo, (1977).

78) Text of Lecture Meeting on " Recent Hydraulics Technology".

79) Nomura et al.: Rolling Theory Committee Report, Joint Research Soc., ISIJ, (1974), 105-127.

80) Hata et al.: The Hitachi Hyoron, 56 (1974), No. 10, 9-26.
81) Maskrey and Thayer: J. Dynamic Systems, Measurement, and Control, 100 (1978), 110-116.

82) Yokote: Tetsu-to-Hagané, 62 (1976), 741.

83) Yokote: J. Japan Soc. Tech. Plasticity, 14 (1973), No. 154, 11.

84) Suzuki: J. Japan Soc. Mech. Eng., 78 (1975), No. 683.

85) Yamachika: Tribology Kiso to Ouyo-I.

86) Tamatsugi: Ishikawajima-Harima Eng. Rev., 9 (1969).

87) Furutsu: Koyo Eng. J., (1970), No. 117.

88) Kuboi: NSK Bearing J., (1972), No. 630

89) Hori: NSK Bearing J., (1970), No. 624.

90) Suzuki: Kikai Sekkei, 21 (1977), No. 12.

91) Koyanagi: Kinzoku, 45 (1975), No. 7.

92) Kakuta: Seimitsu Kikai, 39, No. 3.

93) Moritani: Kinzoku Zairyo, 10, No. 5.

94) Kunou: Tetsu-to-Hagané, 59 (1973), 1764.

95) Yokote: J. Japan Soc. Tech. Plasticity, 17 (1976), No. 188, 9.

96) Kajiwara: Tetsu-to-Hagané, 59 (1973), 1863.

97) Gichelli: Backup Roll Bearing of Cold Rolling Mill.

98) Yamada: Junkatsu Tsushin, (1977), June.

99) Tsuji: Junkatsu Tsushin, (1977), June.

100) Toda: Tribology Kiso to Ouyo-I.

101) Uchida: NSK Bearing J., (1973), No. 633.

102) Koyama and Kubota: Mitsubishi Denki Giho, 48 (1974), No. 2.

103) Thomas et al.: IASE, (1969), No. 5.

104) Honjo et al.: Ishikawajima-Harima Eng. Rev., 17 (1977), No. 6, 11.

105) Kashay: IASE, (1973), No. 7.

106) Takeshita et al.: Preprints for The Japan Society of Mechanical Engineers Meeting, No. 770-3, (April, 1977).

107) Monace: IASE, (1977), No. 12.

108) Takeshita: Preprints for The Japan Society of Mechanical Engineers Meeting, No. 361, (September, 1976).

109) The Brown Boveri Review, (1966), No. 9.

110) Tanaka et al.: Mitsubishi Juko Giho, 7 (1970), No. 2, 3.

111) Miyashita: Tetsu-to-Hagané, 57 (1971), 696.

112) Yamada: Tetsu-to-Hagané, 57 (1971), 773.

113) Kodaira et al.: Seitetsu Kenkyu, 278 (1973).

114) Sato and Kodaira: Tetsu-to-Hagané, 57 (1971), 738.

115) Kubo et al.: Tetsu-to-Hagané, 57 (1971), 808.

116) Hayashi: “ $R$ \& $D$ ” Kobe Steel Engineering Reports, 26 (1976), No. 3.

117) Yoshida et al.: Kinzoku, Special Issue, (1977), 78.

118) Blaskovich: Iron Steel, (1975), No. 12.

119) ex., Tetsu-to-Hagané, 57 (1971), No. 5.

120) Ikedaka and Nohara: Tetsu-to-Hagané, 57 (1971), 795.

121) Nakagawa: Tetsu-to-Hagané, 64 (1978), 113.

122) Nakagawa: Chuko to Tanko, 268 (1978), 33.

123) Niki: Kinzoku, (1968), No. 3, 45.

124) Kouno et al.: " $R$ \& $D$ " Kobe Steel Engineering Reports, 21 (1971), No. 3.

125) Tokumitsu: Tetsu-to-Hagané, 64 (1978), 123.

126) Shigematsu et al.: Kikai Sekkei, 22 (1978), No. 3, 93.

127) Maeda et al.: Kikai Sekkei, 22 (1978), No. 1, 93.

128) Sudo: Netsu Shori, 15 (1975), 319.

129) Iwata: J. Japan Soc. Mech. Eng., 77 (1974), No. 669, 37.

130) Report to Hot Strip Subcomm., Steel Plate and Wire Comm., Joint Research Soc., ISIJ, (1976).

131) Report to the 27th Hot Strip Subcomm., Steel Plates and Sheets Comm., Joint Research Soc., ISIJ, (1978).

132) Seitetsu Kenkyu, 293 (1978), 65-73.

133) ex., Patent Specification, S53-14675, (1978).

134) Report to Heat Economy Technology Comm., Joint Research Soc., ISIJ, (1977).

135) Report to the 28th Hot Strip Subcomm., ISIJ, (May, 1978). 
136) Ohta: Notes to the 14th Sosei Kako Meeting, the Kansai Branch.

137) Nakagawa et al.: Patent Publication, S50-36350, (1975).

138) Tamaki: Keisoku Gijutsu, 2 (1974), No. 10, 115.

139) Tsuchiya et al.: Seitetsu Kenkyu, 293 (1978), 65.

140) Tsuji: Patent Specification, S48-90320, (1973).

141) ex. Okado and Nakauchi: Preprints of the 27th Plastic Working Joint Lecture Meeting, (1976), 81.

142) ex., Ohike et al.: Tetsu-to-Hagané, 63 (1977), S222.

143) ex., Kikawa et al.: Tetsu-to-Hagané, 64 (1978), S700.

144) ex., Furukawa et al.: Tetsu-to-Hagané, 64 (1978), S703.

145) ex., Kigawa et al.: Preprints of the 28th Plastic Working Joint Lecture Meeting, (1977), 88.

146) Suzuki et al.: Text of the 61st Sosei Kako Symposium, (1977).

147) Jishi et al.: Preprints of the 26th Plastic Working Joint Lecture Meeting, (1975), 53.

148) Akasaka and Kouno: Tetsu-to-Hagané, 62 (1976), S617.

149) Kitamura et al.: Preprints of the 28th Plastic Working Joint Lecture Meeting, (1977), 92.

150) Shiozaki et al.: Preprints of Showa 53 Nen Sosei Kako Shunki Koenkai, (1978), 33.

151) Yoshida et al.: Patent Publication, S51-79669, (1976).

152) ex., Tozawa et al.: J. Japan Soc. Tech. Plasticity, 17 (1976),
No. $180,37$.

153) ex., Honjo: Ishikawajima-Harima Eng. Rev., 15 (1975), No. 4, 515.

154) Katou: Kinzoku Sosei Kakogaku, Maruzen, Tokyo, (1971).

155) Okamoto: Tetsu-to-Hagané, 63 (1977), 537.

156) ex., Katou: Patent Publication, S52-109464, (1977).

157) Watanabe et al.: Tetsu-to-Hagané, 63 (1977), S213.

158) Senami et al.: Preprints of Showa 52 Nen Sosei Kako Shunki Koenkai, (1977), 117.

159) ex., Chino et al.: Patent Specification S52-1700, (1977).

160) Shiozaki et al.: Preprints of Showa 53 Nen Sosei Kako Shunki Koenkai, (1978), 33.

161) Kamii et al.: J. Japan Soc. Tech. Plasticity, 17 (1976), 966.

162) Coffin: J. Metals, (1967), No. 4, 178.

163) Saxl: Metals \& Materials, (1973), No. 4, 178.

164) Fröhling et al.: Metall, 28 (1974), No. 4, H4, 331.

165) Gebauer et al.: Metals Tech., (1978), No. 4, 122.

166) Rittinghaus: Stahl u. Eisen, 98 (1978), No. 5, S194.

167) Sumitomo Metal Industries, Ltd.: Report to the 58th Rolling Theory Comm., Joint Research Soc., ISIJ, (June, 1977).

168) Kawarada et al.: Tetsu-to-Hagané, 64 (1978), S683.

169) Stahl u. Eisen, 93 (1973), No. 22. 